\title{
EFEITO DO USO DE POLÍMERO HIDRORETENTOR NO SOLO SOBRE O INTERVALO DE IRRIGAÇÃO NA CULTURA DA ALFACE (Lactuca sativa L.)
}

\section{OdaIR Moraes}

Engenheiro Agrônomo

Orientador: Prof. Dr. TARLEI ARRIEL BOTREL

Tese apresentada à Escola Superior de Agricultura "Luiz de Queiroz", Universidade de São Paulo, para obtenção do título de Doutor em Agronomia, Área de Concentração: Irrigação e Drenagem.

\section{P I R A C I C A B A}

Estado de São Paulo - Brasil

Fevereiro - 2001 
Dados Internacionais de Catalogação na Publicação (CIP) DIVISĀO DE BIBLIOTECA E DOCUMENTAÇĀO - Campus "Luiz de Queiroz"/USP

Moraes, Odair

Efeito do uso de polimero hidroretentor no solo sobre o intervalo de irrigação na cultura da alface (Lactuca sativa L.) / Odair Moraes. - - Piracicaba, 2001.

$73 \mathrm{p}$.

Tese (doutorado) - Escola Superior de Agricultura Luiz de Queiroz, 2001.

Bibliografia.

1. Alface 2. Irrigaçăo 3. Polimero 4. Retenção de água no solo 5. Solo argiloso I. Título

CDD 635.52

Mermitua a con h total ou narcial deste iocumento, desde que citada a fonte o autor 
A memória de meus queridos pais, Odilon e Martba.

À minba mulber, Rosalina,
e ao meu filbo, Júlio Contier.

DEDICO. 


\section{AGRADECIMENTOS}

A Deus, pela fé e esperança.

À Escola Superior de Agricultura "Luiz de Queiroz" (ESALQ/USP), por intermédio do Departamento de Engenharia Rural, pela acolhida e apoio dispensados.

À Universidade Estadual de Londrina (UEL), pela licença concedida para a realização do curso.

À Coordenação de Aperfeiçoamento de Pessoal de Nível Superior (CAPES), pela concessão de bolsa de estudos.

Ao prof. Dr. Tarlei Arriel Botrel, pela orientação, amizade e apoio recebidos no decorrer do curso e na realização deste trabalho.

Aos demais professores e colegas de curso, pelos ensinamentos e sugestões recebidas durante a realização do curso de Pós-Graduação.

Aos funcionários do Departamento de Engenharia Rural, e em especial do Laboratório de Hidráulica, pela colaboração na condução dos ensaios.

Enfim, a todos que, direta ou indiretamente, contribuíram para a realização deste trabalho. 


\section{SUMÁRIO}

Página

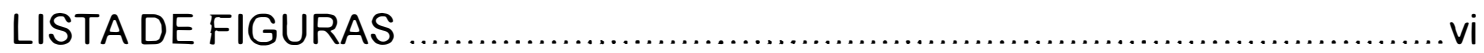

LISTA DE TABELAS .................................................................. vii

LISTA DE ABREVIATURAS E SÍMBOLOS ..........................................

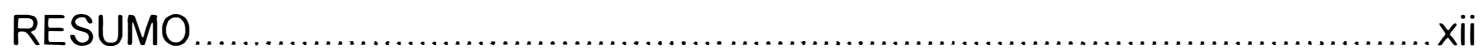

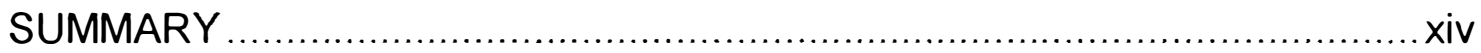

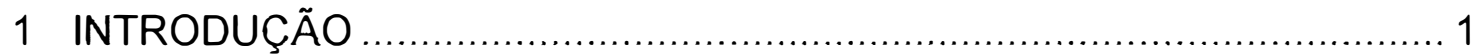

2 REVISÃO DE LITERATURA

2.1 O que são polímeros hidroretentores ? ................................... 5

2.2 Pesquisas com polímeros hidroretentores ...................................... 9

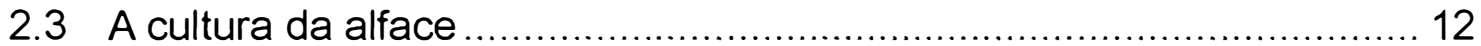

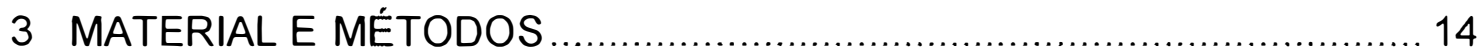

3.1 Delineamento experimental ...................................................... 15

3.2 Desenvolvimento do sistema de irrigação .................................... 17

3.3 Ensaio para determinação da vazão dos orifícios ........................... 22

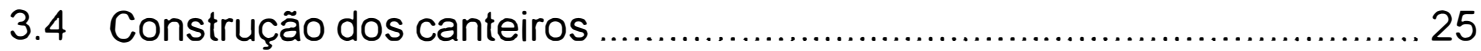

3.5 Incorporação do produto ao solo .................................................. 27

3.6 Elaboração da curva de retenção de água do solo........................... 28

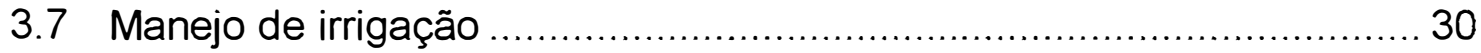

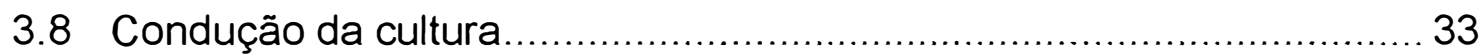

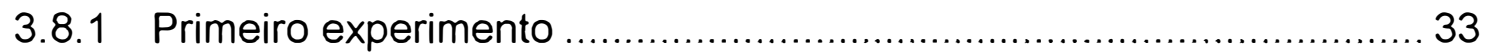

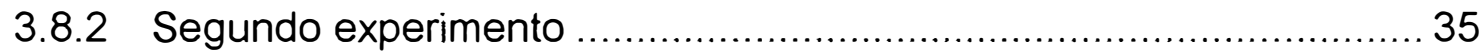

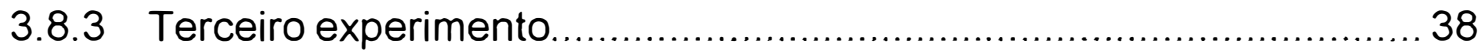

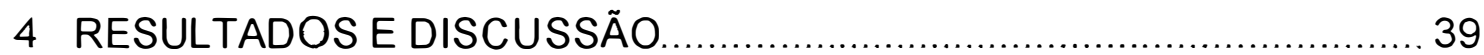

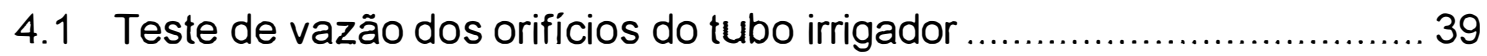

4.2 Curva de retenção de água .................................................. 43 
4.3 Análise dos experimentos................................................ 47

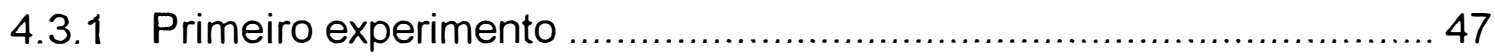

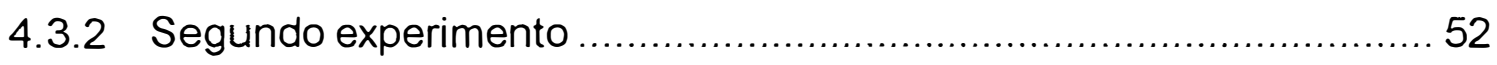

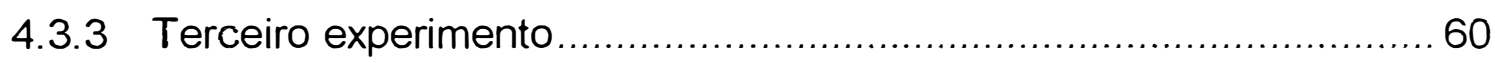

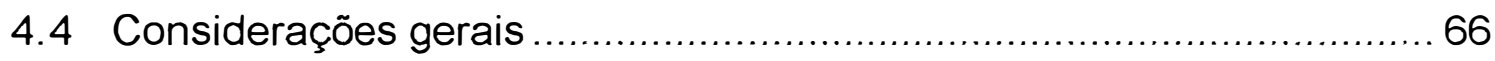

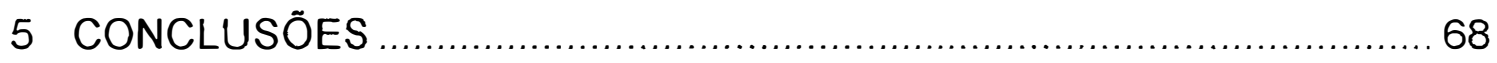

REFERÊNCIAS BIBLIOGRÁFICAS ........................................... 70 


\section{LISTA DE FIGURAS}

Página

1 Vista do carrinho com o tubo irrigador colocado sobre os trilhos. 18

2 Vista dos trilhos de arame fixados aos mourões.

3 Detalhes do sistema utilizado para tracionamento do carrinho com o tubo irrigador.

4 Detalhe da colocação do carretel de PVC na polia do sistema de tracionamento do carrinho com o tubo irrigador.

5 Detalhes da disposição dos canteiros e distribuição dos tratamentos utilizados no primeiro experimento.

6 Vista geral dos canteiros de alface no segundo experimento.

7 Curva vazão vs. pressão determinada para os três tipos de agulhas descartáveis testados

8 Curva vazão vs. pressão obtida para a agulha descartável verde, no segundo ensaio.

9 Curvas de retenção de água no solo, para os respectivos tratamentos de dose do produto hidroretentor

10 Curvas de retenção de água do solo representativas para cada tratamento de dose do produto hidroretentor. 
11 Seqüência dos valores registrados de evaporação do tanque Classe A (Eca), evapotranspiração de referência (ETo), evapotranspiração da cultura (ETc) e eventos de precipitação diária (Prec.), ocorridos durante o primeiro experimento

12 Comparação, em pêntadas, entre a evapotranspiração da cultura e a precipitação ocorridas durante 0 primeiro experimento.

13 Seqüência dos valores registrados de evaporação do tanque Classe A (Eca), evapotranspiração de referência (ETo), evapotranspiração da cultura (ETc) e eventos de precipitação diária (Prec.), ocorridos durante o segundo experimento.

14 Seqüência dos valores registrados de evaporação do tanque Classe A (Eca), evapotranspiração de referência (ETo), evapotranspiração da cultura (ETc) e eventos de precipitação diária (Prec.), ocorridos durante o terceiro experimento. 


\section{LISTA DE TABELAS}

Página

1 Resultados de análise química do solo realizada em agosto de 1998, antes da formação dos canteiros.

2 Análise granulométrica determinada para cada respectivo tratamento de dose do produto hidroretentor.

3 Análise química de solo para cada respectivo tratamento de dose do produto hidroretentor.

4 Resultados dos valores de densidade do solo, calculados para cada fileira de canteiros nos respectivos tratamentos de dose do produto.

5 Valores do teor de umidade do solo $\left(U_{\mathrm{cc}}\right)$, em base gravimétrica, e de lâmina de água $\left(h_{c c}\right)$, em três diferentes tensões de água no solo, para os tratamentos de dose do produto hidroretentor.

6 Dados climáticos registrados durante o ciclo de cultivo da alface no primeiro experimento.

7 Valores das médias das variáveis avaliadas no primeiro experimento.

8 Dados climáticos registrados durante o ciclo de cultivo da alface no segundo experimento. 
9 Valores de lâmina total de irrigação aplicadas aos diferentes tratamentos no segundo experimento.

10 Valores médios obtidos para as variáveis peso fresco (PF) e matéria seca (MS), em cada tratamento de dose do produto (DOSE), para os respectivos intervalos de irrigação (INTER), no segundo experimento.

11 Resultado da análise de comparação de médias para a variável peso fresco (PF), no segundo experimento. 56

12 Resultado da análise de comparação de médias para a variável matéria seca (MS), no segundo experimento.

13 Dados climáticos registrados durante o ciclo de cultivo da alface, no terceiro experimento. 61

14 Valores médios obtidos para as variáveis peso fresco (PF) e matéria seca (MS), em cada tratamento de dose do produto (DOSE), para os respectivos intervalos de irrigação (INTER), no terceiro experimento.

15 Resultado da análise de comparação de médias para a variável peso fresco (PF), no terceiro experimento.

16 Resultado da análise de comparação de médias para a variável matéria seca (MS), no terceiro experimento 


\section{LISTA DE ABREVIATURAS E SÍMBOLOS}

B - teor de Boro do solo, em mg.dm ${ }^{-3}$;

$\mathrm{Ca}$ - teor de Cálcio do solo, em mmolc. $\mathrm{dm}^{-3}$;

cm.c.a. - centímetros de coluna d'água, em cm ;

DL - distância máxima longitudinal das folhas do pé de alface, em cm ;

DOSE - tratamento do fator dose do produto hidroretentor, em g. $\mathrm{m}^{-2}$;

DT - distância máxima transversal das folhas do pé de alface, em $\mathrm{cm}$;

Evap. - evaporação do tanque Classe $A$, em mm. $\mathrm{d}^{-1}$;

$\mathrm{h}_{100}$ - altura de lâmina d'água à uma tensão de $100 \mathrm{kPa}$, em mm. cm ${ }^{-1}$;

$\mathrm{H}+\mathrm{Al}$ - teor de Hidrogênio mais Alumínio, em $\mathrm{mmol}_{\mathrm{c}} \cdot \mathrm{dm}^{-3}$;

$\mathrm{h}_{\mathrm{cc}}$ - altura de lâmina d'água na capacidade de campo, em $\mathrm{mm} \cdot \mathrm{cm}^{-1}$;

Ins. - horas de brilho solar, em h.d $d^{-1}$;

INTER - tratamento do fator intervalo de irrigação, em d;

IR - tratamento para respectivo intervalo de irrigação, em d;

$\mathrm{K}$ - teor de Potássio do solo, em mmolc.dm ${ }^{-3}$;

m.c.a. - metros de coluna d'água, em $\mathrm{m}$;

$\mathrm{Mg} \mathrm{-} \mathrm{teor} \mathrm{de} \mathrm{Magnésio} \mathrm{do} \mathrm{solo,} \mathrm{em} \mathrm{mmol} \mathrm{cm}^{-3}$;

M.O. - teor de matéria orgânica do solo, em g. $\mathrm{dm}^{-3}$;

MS - matéria seca, em g ;

NF - número de folhas do pé de alface, sem a cabeça, em un. ;

$P \quad$ - teor de Fósforo do solo, em $\mathrm{mg} \mathrm{dm}^{-3}$;

PC - peso da cabeça da alface, em g ;

$\mathrm{PF}$ - peso fresco, em g ;

$\mathrm{pH} \quad$ - índice de acidez do solo;

Prec. - precipitação diária, em $\mathrm{mm}$;

R.G. - radiação global, em MJ.m. $\mathrm{m}^{-2} \cdot \mathrm{d}^{-1}$;

SB - soma de bases, em mmolc. $\mathrm{dm}^{-3}$;

$\mathrm{T}$ - tratamento para uma respectiva dose do produto, em g. $\mathrm{m}^{-2}$; 
TFSA - terra fina seca ao ar ;

T.md. - média das temperaturas médias no período, em ${ }^{\circ} \mathrm{C}$;

T.mn. - média das temperaturas mínimas no período, em ${ }^{\circ} \mathrm{C}$;

T.mx. - média das temperaturas máximas no período, em ${ }^{\circ} \mathrm{C}$;

To - total de bases, em mmolc. $\mathrm{dm}^{-3}$;

Trat. - tratamento;

$U_{100}$ - teor de umidade do solo à uma tensão de $100 \mathrm{kPa}, \mathrm{g} \cdot \mathrm{g}^{-1}$;

$U_{c c} \quad$ - teor de umidade do solo na capacidade de campo, em g.g ${ }^{-1}$;

U.R. - umidade relativa média do ar, em \% ;

$\mathrm{V}$ - saturação em bases, em \% ;

Ven. - velocidade do vento média, em $\mathrm{km} \cdot \mathrm{h}^{-1}$;

vs. - versus;

X $\quad$ - expoente da pressão da equação vazão vs. pressão de emissores, adm. 


\section{EFEITO DO USO DE POLÍMERO HIDRORETENTOR NO SOLO SOBRE O INTERVALO DE IRRIGAÇÃO NA CULTURA DA ALFACE (Lactuca sativa L.)}

Autor: ODAIR MORAES

Orientador: Prof. Dr. TARLEI ARRIEL BOTREL

\section{RESUMO}

O objetivo deste trabalho foi verificar o efeito da utilização de um polímero hidroretentor sobre o intervalo de irrigação em horticultura. Para esta finalidade, planejou-se um experimento com três épocas de plantio diferentes (verão, outono e inverno), em um esquema fatorial $4 \times 3$, com delineamento inteiramente casualizado. O experimento foi conduzido na ESALQ/USP (SP, Brasil). Avaliou-se o efeito na produção da cultura da alface (Lactuca sativa L.), com a aplicação de quatro doses do produto $\left(\mathrm{TO}=0 \mathrm{~g} \cdot \mathrm{m}^{-2}, \mathrm{~T} 100=100 \mathrm{~g} \cdot \mathrm{m}^{-2}\right.$, $\mathrm{T} 200=200 \mathrm{~g} \cdot \mathrm{m}^{-2}$ e $\mathrm{T} 300=300 \mathrm{~g} \cdot \mathrm{m}^{-2}$ ) em uma camada de $16 \mathrm{~cm}$ de um solo argiloso, e associados a três intervalos de irrigação (IR1 = 1 dia, IR3 = 3 dias e IR5 = 5 dias). Para irrigação da cultura, desenvolveu-se um sistema constituído por um tubo perfurado com 24 orifícios para saída da água, nos quais foram acopladas agulhas descartáveis. O tubo fixado em um carrinho e colocado em trilhos de arame suspensos sobre os canteiros, foi movimentado por um sistema de tracionamento acionado por motor elétrico de corrente contínua, cuja fonte de alimentação foi uma bateria de 12,0 V. Das três épocas de plantio realizadas, apenas no experimento de outono ocorreu pouca contribuição das chuvas durante o ciclo da cultura. A análise de variância revelou interação entre o efeito de dose do produto e o efeito do intervalo de irrigação. No teste de comparação de médias, para a variável dependente peso fresco (PF), a interação do efeito do fator intervalo de irrigação no tratamento de maior dose 
do produto (T300), não mostrou diferença significativa entre os tratamentos. Já no experimento de outono, a interação do efeito do fator dose do produto no tratamento de maior intervalo de irrigação (IR5), mostrou que o tratamento (T300) diferiu estatisticamente, ao nível de $5 \%$ de probabilidade, dos demais. $\mathrm{Na}$ comparação de médias, para a variável dependente matéria seca (MS), revelou haver apenas diferença estatística no experimento de outono: na interação do efeito do fator intervalo de irrigação no tratamento de maior dose do produto (T300), ocorreu diferença, ao nivel de 5\% de probabilidade, entre os tratamentos IR5 e IR1; e na interação do efeito do fator dose do produto no tratamento de maior intervalo de irrigação (IR5), o tratamento (T300) diferiu estatisticamente, ao nivel de 5\% de probabilidade, dos tratamentos T0 e T200. Estes resultados evidenciaram que houve um efeito na produção da cultura da alface quando se utilizou a maior dose do polímero hidroretentor para um intervalo de irrigação de 5 (cinco) dias. 


\title{
EFFECT OF THE USE OF A WATER RETENTIVE POLYMER IN THE SOIL ON THE IRRIGATION INTERVAL OF LETTUCE (Lactuca sativa L.)
}

\author{
Author: Odair Moraes \\ Adviser: Prof. Dr. Tarlei Arriel Botrel
}

\section{SUMMARY}

The aim of this work was to verify the effect of a water retentive polymer on the irrigation interval in horticulture. Three different planting times (summer, fall and winter) were planned for this experiment in a $4 \times 3$ factorial scheme, in a completely randomized design. The experiment was built at ESALQ/USP (SP, Brazil). The effect on the production of the lettuce (Lactuca sativa L.) crop was evaluated with the application of four rates of the product ( T0 $=0 \mathrm{~g} \cdot \mathrm{m}^{-2}, \mathrm{~T} 100=100 \mathrm{~g} \cdot \mathrm{m}^{-2}, \mathrm{~T} 200=200 \mathrm{~g} \cdot \mathrm{m}^{-2}$, and $\left.\mathrm{T} 300=300 \mathrm{~g} \cdot \mathrm{m}^{-2}\right)$ in a 16-cm layer of clayey soil associated with three irrigation intervals (IR1 = 1 day, IR3 = 3 days, and IR5 = 5 days). In order to irrigate the crop one developed a system made up of a pipe perforated with 24 outlets on which disposable needles were coupled. The pipe, mounted on a small cart and placed in suspended wire tracks on the plots, was moved by a traction system driven by a direct current electric motor, fed by a $12.0 \mathrm{~V}$ battery. Out of the three planting times only at the fall experiment there was scarce rain contribution during the crop cycle. The analysis of variance showed the interaction between the effect of the rate of the product and the effect of the irrigation interval. At the test of mean comparison, for fresh weight dependent variable (PF), the interaction of the effect of the irrigation interval factor on the higher rate of the product 
treatment (T300) showed no significant difference among the treatments. As to the fall experiment, the interaction of the effect of the product's rate factor on the higher irrigation interval treatment (IR5) showed that the treatment (T300) was statistically different at a $5 \%$ probability level. Regarding comparison of means, for the dry matter dependent variable (MS) only statistic difference was observed at the fall experiment after the interaction of the effect of the irrigation interval factor on the higher rate of the product treatment (T300), with a difference at $5 \%$ probability between treatments IR5 and IR1; after the interaction of the effect of the product's rate factor on the higher irrigation interval treatment (IR5), the treatment (T300) was statistically different at 5\% probability from treatments TO and T200. These results point the evidence of an effect on the production of lettuce when the higher rate of water retentive polymer was used for a 5-day irrigation interval. 


\section{INTRODUÇÃO}

O principal problema com solos degradados e de textura arenosa é que eles são caracterizados por uma deficiência de materiais orgânicos e nutrientes, ambos essenciais para formar solos bem estruturados para o crescimento das plantas. Além disto, solos arenosos oferecem pouca disponibilidade hídrica às plantas devido à sua baixa capacidade de retenção de água, o que contribui para uma maior evaporação superficial e maior percolação de água, em função de suas propriedades físicas, e serem, também, sensíveis aos danos provocados pela erosão do vento e da água.

Cientes destas características deste tipo de solo, pesquisadores investigaram a possibilidade do uso de produtos artificiais que assumissem 0 papel da argila e dos adubos compostos na melhoria das condições do solo. Estava aí criado o termo condicionador de solo. Manter o solo mais úmido por um maior período de tempo e estimular a atividade microbiológica, foram os critérios utilizados para se pesquisar estes condicionadores de solo.

Os primeiros condicionadores sintéticos de solo foram introduzidos no início dos anos 50, entre os quais o Krilium (poliacrilonitrita hidrolisada) foi o mais conhecido. Devido à sua habilidade em absorver centenas de vezes seu próprio peso em água, poliacrilamidas e polimetacrilatos (também conhecidos como polímeros absorventes, polimeros super-absorventes ou hidrogéis) foram testados na agricultura, horticultura e paisagismo no início dos anos 60 . 
O interesse desapareceu quando experimentos provaram que os mesmos eram fitotóxicos, devido ao seu alto resíduo do monômero de acrilamida. Muito embora avanços na tecnologia de fabricação diminuíssem a concentração do monômero abaixo do nível de toxidez, a literatura científica mostrou pouco sucesso no uso destes polímeros no aumento da qualidade ou no rendimento das culturas.

O aparecimento de uma nova geração revolucionária de polímeros e co-polímeros das famílias da propenamida e propenamida-propenoato no início dos anos 80 , que passaremos a denominar por polímeros hidroretentores, propiciou a pesquisadores iniciarem uma busca por métodos que permitissem às plantas crescerem e desenvolverem-se em ambientes já degradados pela interferência do homem e/ou da própria natureza, mais com um sentido sócioeconômico, de recuperar áreas para agricultura em regiões de baixíssima disponibilidade hídrica, além de fixar o homem no local, através de uma atividade econômica, como ocorreu, por exemplo, na região denominada por Sahel, no oeste do continente africano.

Além desta aplicação para a qual foi inicialmente desenvolvido, estes polimeros hidroretentores acabaram sendo empregados comercialmente em outros setores, como na agricultura, principalmente em solos arenosos de regiões áridas ou semi-áridas; em cultivos protegidos; na produção de mudas florestais e agrícolas; na estabilização de taludes de terra; em gramados de campos esportivos e em alguns cultivos intensivos, como na horticultura.

Um dos objetivos primordiais na pesquisa é a de tentar-se buscar soluções para problemas presentes ou procurar antecipar situações que poderão ocorrer em futuro próximo, propondo alternativas para enfrentar estes novos desafios. 
Um deles, com certeza, será o de produzir alimentos suficientes para uma população mundial cada vez maior, onde cada vez mais as pessoas tenderão a viver próximas a ou dentro de grandes centros urbanos, gerando uma diminuição crescente no número de pessoas que trabalharão na agricultura.

Em função disto, podemos pensar numa agricultura cada vez mais intensiva, procurando obter produtividades e rendimentos cada vez maiores. Também, podemos pensar na produção agrícola próxima aos grandes centros urbanos, nos chamados cinturões verdes, ou até mesmo, dentro de áreas urbanas.

Para diminuir-se os riscos inerentes à atividade agrícola nestas áreas de produção intensiva, certamente teríamos que pensar em adotar práticas de irrigação visando a suprir a escassez de água em certas épocas, ou pela falta ou pela má distribuição das precipitações naturais. Como os insumos, água e energia, terão um peso considerável no custo de produção desses cultivos irrigados, podemos pensar na utilização de polímeros hidroretentores, em associação com a irrigação, no sentido de diminuir os custos de operação dos sistemas de irrigação.

Como vários produtos comerciais foram utilizados em solos com textura arenosa, onde pesquisas haviam confirmado o efeito benéfico no aumento de retenção de água em solos desta natureza, este trabalho terá como objetivo verificar se o mesmo comportamento de um polimero hidroretentor ocorre quando incorporado a um solo de textura argilosa.

Em função do exposto, pretendemos verificar através de três ciclos distintos no cultivo da cultura da alface (Lactuca sativa L.), se com a incorporação, de forma homogênea, de três doses diferentes de um polímero 
hidroretentor aos canteiros de plantio, em um solo de textura argilosa, e quando associados a três distintos intervalos de irrigação, ocorreria um aumento de produtividade da cultura em função de doses crescentes do produto, em conjunto com o aumento no intervalo de irrigação, quando comparado ao tratamento padrão, sem a incorporação do polímero hidroretentor.

Portanto, se a hipótese de trabalho for confirmada, poder-se-ia recomendar ao produtor de alface a utilização do referido condicionador de solo, em solos de textura argilosa, uma vez que alguns co-polímeros presentes na mistura do produto podem ter uma vida útil de até dez anos de atuação no solo (Terracottem, 1998), e desde que o intervalo de aplicação de água à cultura fosse aumentado, resultando numa economia na operação do sistema de irrigação empregado, pelo melhor aproveitamento da chuva e da lâmina de irrigação. Isto poderia ser confirmado através de uma análise econômica relacionando-se o custo de aquisição e aplicação do polímero hidroretentor com a diminuição no custo de operação do sistema de irrigação. 


\section{REVISÃO DE LITERATURA}

\subsection{O que são polímeros hidroretentores ?}

Polímeros hidroretentores são produtos naturais (derivados do amido) ou sintéticos (derivados do petróleo), que são valorizados por suas habilidades em absorver e armazenar água. De forma granular e quebradiço quando seco, eles se tornam macios e elásticos após expandidos na água.

Os hidroretentores mais freqüentemente usados são os polímeros sintéticos propenamida (originalmente denominados poliacrilamida ou PAM) e os co-polímeros propenamida-propenoato (originalmente conhecidos como poliacrilamida-acrilato ou PAA) usados como floculante, principalmente em fraldas e outros artigos sanitários, e para depósitos de líquidos químicos residuais.

Quimicamente, os polímeros são construídos de uma longa cadeia de unidades estruturais repetidas chamadas monômeros. A polimerização ocorre quando duas ou mais pequenas moléculas se combinam para formar moléculas maiores, ou cadeias de polímeros. Unidas por ligações covalentes, as moléculas individuais são atraídas e ligadas entre si por fortes ligações (pontes) de hidrogênio. Em contato com a água, essas ligações são enfraquecidas e ocorre a expansão. Ligações cruzadas aumentam a capacidade de expansão dos polímeros, e ocorrem quando as cadeias de polímeros estão acopladas formando uma rede tridimensional. 
Muito embora, exteriormente um hidrogel possa parecer semelhante a um outro, a sua construção química e estrutura física podem ser tremendamente diferentes e isto irá afetar a maneira como ele absorverá, reterá e irá liberar seu conteúdo.

Para melhor compreensão deste mecanismo, são apresentados três grupos distintos de polímeros hidroretentores e suas estruturas:

- Grupo 1: a água fica irreversivelmente confinada por uma forte ligação $\mathrm{H}$ - $\mathrm{H}$ (hidrogênio - hidrogênio), permanecendo, portanto, $100 \%$ dentro do hidrogel. Nenhuma água é liberada.

- Grupo II: tem capacidade de absorver enorme quantidade de água, mas uma fraca ligação física evita a permanência da água no hidrogel por longos períodos. A água é perdida dentro de poucos dias.

- Grupo III : a água é confinada por fracas ligações de hidrogênio. Absorve e libera a água por longos períodos de tempo.

Sob a supervisão do Dr. Van Cotthem, do Laboratório de Morfologia, Sistemática e Ecologia da Universidade de Ghent, desenvolveu-se um método científico para estudar os efeitos dos polímeros hidroabsorventes no crescimento das plantas.

Na primeira pesquisa desta natureza, testaram-se cada um dos mais de 200 diferentes polímeros usando-se este método. Os resultados, após um período de vários anos, mostraram que uma pequena porcentagem (menos que $5 \%$ ) de polímeros hidroretentores teve uma influência positiva no 
crescimento das plantas. Dentre estes produtos do Grupo III anteriormente mencionado, verificou-se que alguns polímeros:

- aumentavam a produção de biomassa;

- aumentavam a eficiência no uso da água;

- aumentavam a taxa de germinação;

- aumentavam o crescimento lateral das raízes.

Um segundo programa de pesquisa foi implementado para estudar a influência sobre o crescimento das plantas de substâncias adicionais misturadas a estes polímeros, tais como: casca de cacau, fertilizantes orgânicos e inorgânicos, proteínas, amidos, entres outras. A pesquisa mostrou que, em combinação com os polímeros hidroretentores, uma certa mistura de fertilizantes e elementos estimulantes de crescimento teve uma influência extremamente positiva no desenvolvimento das plantas e na melhoria das características do solo. Ao mesmo tempo, a pesquisa também mostrou que havia uma faixa muito estreita onde a combinação de hidrogéis e fertilizantes trabalham em grande sinergia. Um excesso de fertilizantes diminuía a capacidade de retenção de água do hidrogel, enquanto uma quantidade diminuta de fertilizante conferia pouca ou nenhuma influência positiva na raiz ou na produção de biomassa da planta.

A pesquisa conduzida pela equipe da Universidade de Ghent resultou no condicionador de solo denominado por TerraCottem ${ }^{1}$, o qual será objeto de estudo neste trabalho de tese.

\footnotetext{
${ }^{1}$ TerraCottem - nome comercial do produto utilizado no rabalho, que será referenciado como polímero hidroretentor.
} 
Segundo informações dos fabricantes e fornecedores do produto (Terracottem, 1998), este é composto por uma mistura de 23 componentes que trabalham em sinergia para melhorar as condições de crescimento e desenvolvimento das plantas, reduzindo ainda a necessidade de irrigação, fertilização e manutenção. Também, informa-se que foram realizados dez anos de testes, tanto em laboratório como no campo, antes do produto ser comercialmente viável em escala internacional, a partir de 1993.

O produto contém uma mistura de diferentes co-polímeros propenamida-propenoato. Esta mistura proporciona um efeito muito mais abrangente do que cada um dos polímeros isoladamente. Ao contato com a água, eles absorvem rapidamente as moléculas de água para formar uma substância gelatinosa e insolúvel capaz de armazenar até cem vezes seu próprio peso em água.

Os polímeros proporcionam numerosos ciclos de absorção e liberação da água, por um longo tempo de utilização. Sua alta estabilidade biológica e mecânica assegura eficiência no seu uso em áreas tropicais e subtropicais, com climas áridos e semi-áridos.

Os polímeros hidroretentores absorvem (processo físico) e armazenam a água de chuva ou de irrigação, que normalmente podem se perder por evaporação, escorrimento superficial ou percolação, reduzindo o volume e a freqüência necessária de irrigação em 40 a 60\%. Esta água, então, é mantida à disposição da planta.

Uma vez adicionado ao solo, os polímeros retém esta água e a estocam de forma que a raiz da planta possa absorvê-la através dos seus pêlos absorventes, mantendo-a nesta situação por um período maior de tempo. Em condições de seca o hidrogel ajuda a diminuir o processo de dessecação da 
raiz e permite às plantas sobreviverem, e continuarem crescendo, em condições áridas ou semi-áridas.

A água aplicada para irrigar o solo tratado é retida a uma taxa muito maior e utilizada mais eficientemente do que aquela aplicada em solo não tratado, reduzindo o volume e a freqüência de irrigação necessária.

Os polímeros hidroretentores absorvem (processo químico) nutrientes minerais e orgânicos, aumentando a eficiência ecológica de aproveitamento dos fertilizantes.

Muitos fertilizantes e nutrientes que são normalmente lixiviados do solo para os rios, correntezas, aqüíferos e outras fontes de água pura são capturados pelos hidrogéis e potencialmente disponibilizados para as plantas. A capacidade de troca cationica ou CTC (que quantifica a capacidade de um solo de prover nutrientes para a planta, por medição de sua habilidade de trocar cátions) dos polímeros hidroretentores é muito alta quando comparada com a maioria dos tipos de solo. Pela capacidade de reterem elementos nutrientes, os polímeros contribuem diretamente para a nutrição da planta e podem reduzir o consumo de fertilizantes entre 20 a $50 \%$.

\subsection{Pesquisas com polímeros hidroretentores}

Sobre a nova geração de materiais sintéticos, Smagin \& Sadovnikova (1995), os quais chamaram de hidrogéis polímeros fortemente expandidos (SPH), relatam que eles pertencem a uma classe de absorventes de água e são usados em práticas de melhoramento agrícola para aumentar a capacidade de retenção de água do solo. Os autores comentam que a incorporação do SPH no solo impede a realização completa desta propriedade, 
devido a um espaço poroso limitado. O comportamento deste polímero no ambiente do solo é praticamente não conhecido, especialmente sua resistência à decomposição e lixiviação. Além disso, um aumento na capacidade de retenção de alguma camada fina de solo é insuficiente para otimização de seu regime hídrico, desde que o mesmo é ditado pelo movimento da água em todo o perfil de solo, juntamente com as taxas de entrada de água e perdas de água por evapotranspiração.

Salem et al. (1991), avaliaram a habilidade de um hidrogel de poliacrilamida em aumentar a capacidade de retenção de água de um solo arenoso sob diferentes condições de salinidade. A taxa de aplicação do hidrogel de $1 \mathrm{~g}$ por quilo de solo aumentou a capacidade de retenção de água do solo, mesmo a altos valores de condutividade elétrica. Os efeitos na redução do total máximo de água retida pelo hidrogel foi mais pronunciado para os cátions do que para os ânions.

El Hady et al. (1990), estudaram os efeitos de um hidrogel de poliacrilamida em um solo arenoso, no Egito, usando-se a cultura da ervilha. $O$ sistema de irrigação empregado foi a aspersão, com diferentes porcentagens das necessidades de água da cultura aplicadas a intervalos de 7 dias. Os tratamentos adotados para este condicionador aumentaram o peso fresco das plantas e a absorção de N, P e K. O consumo de água diminui, e aumentou a eficiência do uso de água e fertilizantes pelas plantas.

Nissen (1994), verificou que com o uso de hidrogel aplicado próximo às raízes das plantas, em pomares de framboesas vermelhas (Rubus idaeus), no sul do Chile, a produção de frutos pode ser aumentada de 37 a $86 \%$, o diâmetro do fruto aumentou entre 0,7 a 3,0\% e o peso do fruto entre 3 a $33 \%$. A renda líquida adicional devida à aplicação do hidrogel na framboesa vermelha justificou esta prática. 
Al Darby (1996), realizou um estudo de laboratório conduzido em um solo arenoso, para investigar o efeito de um condicionador de solo na forma de gel sobre o relacionamento da retenção de água no solo, sobre a difusividade de água no solo e sobre a condutividade hidráulica saturada. $\mathrm{O}$ estudo revelou que a adição do condicionador melhorou as propriedades hídricas do solo arenoso e que a melhor taxa do produto foi $0,4 \%$. Esta taxa limitou as perdas por percolação profunda enquanto manteve adequadas a infiltração e características de retenção de água.

Prevedello \& Balena (2000), estudaram o efeito de um polímero hidroretentor, que foi o mesmo utilizado neste trabalho, sobre as propriedades físicas e hídricas de dois meios porosos de distintas propriedades físicoquímicas: um Latossolo vermelho escuro (LE), textura argilosa, e uma areia marinha do litoral paranaense. O estudo foi realizado em laboratório com os materiais porosos, na forma de TFSA, sendo acondicionados em cilindros, com diferentes concentrações do produto. Os autores consideraram que o efeito do polímero hidroretentor sobre as propriedades físicas e hídricas dos dois meios porosos foi consideravelmente marcante. A capacidade de retenção de água no solo argiloso, para a concentração de $32,0 \mathrm{~kg} \cdot \mathrm{m}^{-3}$ foi acrescida cerca de 2 vezes, enquanto que para a areia marinha esse valor foi de 7,5 vezes. Os valores dos diâmetros de poros que armazenam mais água foram bem superiores quando da incorporação de polímeros, para os dois meios porosos, chegando a aumentar o diâmetro em até cerca de 4 vezes. De modo geral, a partir das concentrações de $8,0 \mathrm{~kg} \cdot \mathrm{m}^{-3}$, as propriedades físicas e hídricas dos dois meios porosos foram dominadas pelo efeito dos polímeros.

Ressalte-se que estas conclusões foram baseadas sobre testes de laboratório realizados com concentrações do produto hidroretentor muito maiores do que aquelas utilizadas no presente trabalho, onde o tratamento com maior concentração do produto não ultrapassa de $2,0 \mathrm{~kg} \cdot \mathrm{m}^{-3}$. 


\subsection{A cultura da alface}

A alface é uma planta herbácea anual, muito delicada, com caule diminuto, não ramificado, ao qual se prendem as folhas. Estas são muito lisas ou crespas, fechando-se ou não na forma de cabeça. Suas raízes podem atingir até $60 \mathrm{~cm}$ de profundidade, porém exploram apenas $25 \mathrm{~cm}$ do solo. A alface é uma cichoriácea de inverno, capaz de resistir a baixas temperaturas e a geadas leves. Nota-se que as cultivares produzem melhor sob temperatura amena, sendo que a temperaturas mais elevadas $\left(20-30^{\circ} \mathrm{C}\right)$ aceleram o ciclo cultural e resultam em plantas menores, caindo a produtividade (Filgueira, 1982).

Blanco et al. (1997), relatam que as raízes da alface são do tipo pivotante, com finas ramificações que exploram os primeiros $25 \mathrm{~cm}$ do solo.

A época de plantio mais recomendada no planalto é de março a setembro, porém nas regiões serranas planta-se o ano todo. Quanto ao espaçamento sugere-se $20 \times 20 \mathrm{~cm}, 25 \times 25 \mathrm{~cm}$ ou $30 \times 30 \mathrm{~cm}$, com o plantio em patamares (200, 1994).

Segundo Blanco et al. (1997), a calagem do solo deve ser feita para que a saturação em bases seja elevada a $80 \%$, quando a análise do solo indicar valores inferiores a esse.

Segundo Knott, citado por Branco et al. (1962), a alface é uma cultura que retira, por hectare de solo, aproximadamente, $56 \mathrm{~kg}$ de nitrogênio, $10 \mathrm{~kg}$ de fósforo e $101 \mathrm{~kg}$ de potássio.

No momento do preparo do solo pode-se adicionar 60-70 t.ha ${ }^{-1}$ de esterco de curral bem curtido, ou um quarto dessa quantidade de esterco de galinha, pelo menos dez dias antes da semeadura ou do transplante de mudas. 
Em cobertura deve-se realizar duas aplicações de $30 \mathrm{~kg} \cdot \mathrm{ha}^{-1}$ de nitrogênio aos 30 e 45 dias após a germinação (semeadura direta). No caso de transplante de mudas, aplicar três coberturas de $20 \mathrm{~kg} \mathrm{ha}^{-1}$ de nitrogênio aos 10,20 e 30 dias, após o transplante das mudas (Raij et al., 1992).

O salitre do Chile e a uréia são os elementos responsáveis pelos maiores acréscimos verificados na cultura da alface, promovendo aumentos de $53 \%$ em relação ao tratamento PK (Couto et al., 1963).

Simão (1959), observou que a irrigação com nitrato de sódio a $0,1 \%$ cada três dias proporcionou melhores resultados do que o tratamento com uma aplicação semanal, afirmando a importância do parcelamento do nitrogênio.

A alface é, dentre as hortaliças, uma das que maior quantidade de água retiram do solo. Quando o teor de água no solo cai abaixo da metade do intervalo entre a capacidade de campo e o ponto de murchamento permanente, - crescimento da alface é prejudicado e então obtém-se plantas com crescimento menor, folhas menores e cabeças pequenas (Simão, 1956).

Quanto à irrigação, Hamada \& Testezlaf (1995), concluíram que até 22 dias após o transplante pode-se aplicar lâminas menores de água. $\mathrm{Na}$ fase final, recomenda-se lâminas maiores, pois neste período a cultura apresenta melhor resposta ao insumo água.

Segundo Demattê et al. (1981), comparativamente com o sistema de irrigação por aspersão, o gotejamento proporcionou melhores resultados para diâmetro e altura média da parte aérea, porcentagem de plantas comerciáveis, peso médio da parte aérea e peso médio por metro quadrado cultivado, o qual foi 1,23 vezes superior. 


\section{MATERIAL E MÉTODOS}

Para verificação da hipótese formulada neste trabalho, planejou-se a realização de um experimento de campo, utilizando-se a cultura de alface para observação da influência de diferentes concentrações do polímero hidroretentor incorporadas a um solo de textura argilosa, em conjunto com a aplicação da mesma lâmina de irrigação, adotando-se três intervalos de irrigação distintos.

O experimento foi conduzido na área experimental de irrigação do Departamento de Engenharia Rural da Escola Superior de Agricultura "Luiz de Queiroz" (ESALQ), Universidade de São Paulo (USP), em Piracicaba, estado de São Paulo, Brasil.

As coordenadas geográficas do posto agrometeorológico do Departamento de Ciências Exatas (LCE) da ESALQ/USP, em Piracicaba, SP, situado a cerca de $800 \mathrm{~m}$ do local do experimento, são: latitude $22^{\circ} 42^{\prime} 30^{\prime \prime}$ sul, longitude $47^{\circ} 38^{\prime} 30^{\prime \prime}$ oeste e altitude $546 \mathrm{~m}$.

O solo do local onde foi instalado o experimento de campo foi classificado como terra roxa estruturada, série Luiz de Queiroz, cujo material de origem são as rochas básicas. Possui a classe textural classificada como Argila, densidade do solo média de $1,41 \mathrm{~g} . \mathrm{cm}^{-3}$, com os limites superior e inferior de água disponivel igual a 0,35 e $0,28 \mathrm{~cm}^{3} \cdot \mathrm{cm}^{-3}$, referentes às tensões de $0,01 \mathrm{e}$ $0,10 \mathrm{Mpa}$, respectivamente (Folegatti, 1985). 
Os canteiros foram construídos em uma área praticamente em nível, sistematizada anteriormente e proveniente de um corte de talude.

Realizaram-se três ensaios em diferentes épocas de plantio: o primeiro, na estação de verão; o segundo, na estação de outono; e o terceiro, na estação de inverno.

Em outro experimento conduzido próximo ao local de instalação dos canteiros, realizou-se uma análise química do solo em agosto de 1998, cujos resultados, apresentados na Tabela 1, serviram de base para a recomendação de adubação e calagem para o primeiro experimento.

Tabela 1. Resultados de análise química do solo realizada em agosto de 1998, antes da formação dos canteiros.

\begin{tabular}{|c|c|c|c|c|c|c|c|c|c|}
\hline $\mathrm{pH}$ & M.O. & $P$ & $K$ & $\mathrm{Ca}$ & $\mathrm{Mg}$ & $\mathrm{H}+\mathrm{Al}$ & $S B$ & $T_{0}$ & V \\
\hline$\left(\mathrm{CaCl}_{2}\right)$ & g. $\mathrm{dm}^{-3}$ & $\mathrm{mg} \cdot \mathrm{dm}^{-3}$ & \multicolumn{6}{|c|}{$\mathrm{mmol}_{\mathrm{c}} \cdot \mathrm{dm}^{-3}$} & $\%$ \\
\hline 5,9 & 21 & 8 & 4,2 & 34 & 14 & 29 & 52,0 & 81,3 & 64 \\
\hline
\end{tabular}

\subsection{Delineamento experimental}

Como o objetivo do trabalho foi testar a influência de diferentes concentrações do polímero hidroretentor incorporadas ao meio poroso de um solo de textura argilosa, em relação à capacidade de retenção de água do solo, partiu-se de uma concentração recomendada pelo fabricante do produto a ser aplicada em horticultura, que será comparada com mais duas concentrações: uma com $50 \%$ a menos e outra com $50 \%$ a mais do produto, respectivamente, em relação à concentração do polímero hidroretentor considerada como normal. 
Também, para comparar-se a influência da presença do produto neste tipo de solo a ser estudado, considerou-se mais um tratamento de controle (testemunha), onde não foi incorporado o produto.

Portanto, definiu-se para o experimento quatro tratamentos, a seguir relacionados:

TO - sem aplicação do produto (testemunha)

T100 - concentração baixa do produto (100 g.m $\left.\mathrm{m}^{-2}\right)$

T200 - concentração normal do produto $\left(200 \mathrm{~g}^{-\mathrm{m}^{-2}}\right)$

T300 - concentração alta do produto $\left(300 \mathrm{~g} \cdot \mathrm{m}^{-2}\right)$

Estes tratamentos foram distribuídos ao acaso, por sorteio, ao longo de três fileiras de canteiros, onde foram aplicados os três tratamentos de intervalo de irrigação, a seguir relacionados:

IR1 - intervalo de irrigação diário (1 dia)

IR3 - intervalo de irrigação de 3 dias

IR5 - intervalo de irrigação de 5 dias

Também, os tratamentos de irrigação foram definidos ao acaso, por sorteio, entre as três fileiras de canteiros.

Desta forma, como tivemos quatro tratamentos de concentração do produto repetidos nos três tratamentos de intervalo de irrigação, utilizou-se, para a análise estatística das variáveis resposta, um esquema fatorial $4 \times 3$, com um delineamento inteiramente casualizado. 


\subsection{Desenvolvimento do sistema de irrigação}

Para atender a necessidade de irrigação da cultura desenvolveuse um sistema de irrigação específico para aplicar a lâmina de água aos canteiros.

Utilizou-se um tubo de cobre de $22 \mathrm{~mm}$ de diâmetro e 1,47 $\mathrm{m}$ de comprimento, como meio para aplicar-se a lâmina de irrigação sobre os canteiros.

Numa das extremidades deste tubo foi acoplada uma luva de PVC de $20 \mathrm{~mm}$ (3/4"), na qual fez-se uma rosca para instalar-se uma conexão de saída para tomada da pressão na entrada deste tubo, que passaremos a chamar de tubo irrigador. Na seqüência foi conectado um registro de esfera de $16 \mathrm{~mm}$ (1/2"), junto com uma curva de $90^{\circ}$ de PVC e um terminal de conexão rápida, onde o fornecimento de água ao tubo irrigador foi feito através de uma mangueira transparente flexivel de $16 \mathrm{~mm}\left(1 / 2^{\prime \prime}\right)$, que se deslocou ao longo dos canteiros.

$\mathrm{Na}$ extremidade oposta foi acoplado um registro de esfera de 20 mm (3/4") junto com um adaptador de polietileno, também de 20 mm (3/4") de diâmetro, tendo por finalidade, quando colocado na posição de abertura, retirar o ar presente na água, que eventualmente poderia encontrar-se retido no interior das canalizações do sistema de irrigação, antes do início da operação para aplicação da lâmina de água.

Ao longo do tubo irrigador foram perfurados, a partir de $16 \mathrm{~cm}$ do início do tubo, com uma broca de $1,0 \mathrm{~mm}$ de diâmetro, 24 orifícios com um espaçamento de $5 \mathrm{~cm}$ entre eles. 
O tubo irrigador foi fixado no centro de uma estrutura de madeira, no formato de um retângulo, onde nas quatro extremidades colocou-se parafusos para funcionarem como eixos para quatro rodinhas de $7,5 \mathrm{~cm}$ de diâmetro, construídas com madeira.

Nestas rodinhas, com espessura de $1,4 \mathrm{~cm}$, foram feitas ao longo de sua circunferência, ranhuras com $0,8 \mathrm{~cm}$ de largura por $0,8 \mathrm{~cm}$ de profundidade, tendo por finalidade fazer com que o carrinho fosse mantido alinhado, sustentado e auxiliado no seu deslocamento longitudinal sobre dois trilhos de arame suspensos e colocados separados por uma distância de 1,5 m, ao longo de cada uma das três fileiras de canteiros.

O carrinho com o tubo irrigador, colocado sobre os trilhos de arame, é mostrado na Figura 1.

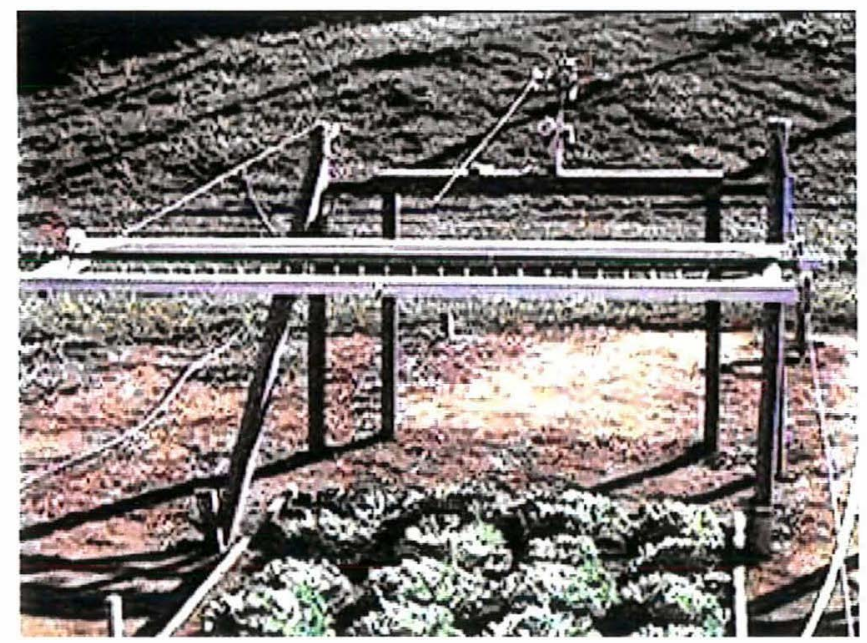

Figura 1 - Vista do carrinho com o tubo irrigador colocado sobre os trilhos.

Estes trilhos de arame ficaram suspensos pela fixação dos mesmos em mourões colocados nas extremidades de cada fileira de canteiros. 
Os trilhos de arame fixados aos mourões e esticados ao longo dos canteiros, podem ser vistos na Figura 2.

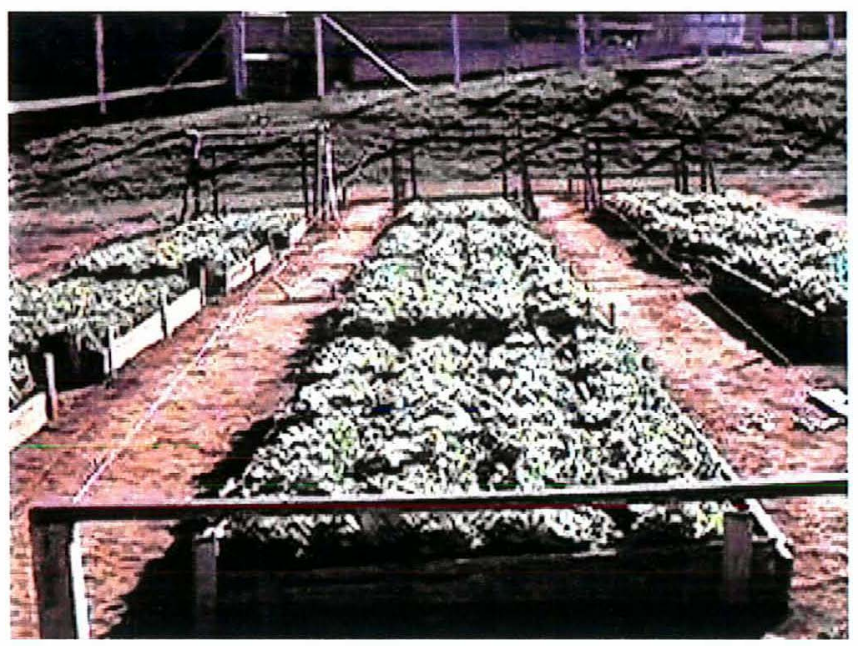

Figura 2 - Vista dos trilhos de arame fixados aos mourões.

Os dois mourões colocados no início de cada fileira de canteiros ficaram com uma altura de 1,20 m acima do solo; e os dois mourões colocados no final ficaram com uma altura de 0,50 $\mathrm{m}$ acima do solo. Portanto, os trilhos de arame galvanizado ficaram com um desnível de 0,70 m.

Não utilizou-se o mesmo nível entre os mourões, porque quando o carrinho com o tubo irrigador estivesse se movimentando na região mediana dos canteiros poderia formar uma catenária, em função de seu peso, o que provocaria uma variação na velocidade de deslocamento do mesmo.

A lâmina de irrigação aplicada pelo carrinho com o tubo irrigador foi determinada pela vazão total de água incorporada à área de cada canteiro, em função da velocidade de deslocamento do carrinho. 
Portanto, para que a lâmina de irrigação fosse mantida constante ao longo de todo o trajeto sobre cada fileira de canteiros, houve a necessidade de construir-se um sistema de tracionamento para manter constante a velocidade de deslocamento do carrinho.

Para o sistema de tracionamento (Figura 3), utilizou-se um motor de limpador de pára-brisas de automóvel, cuja fonte de alimentação de energia foi uma bateria de automóvel de 12,0 V.
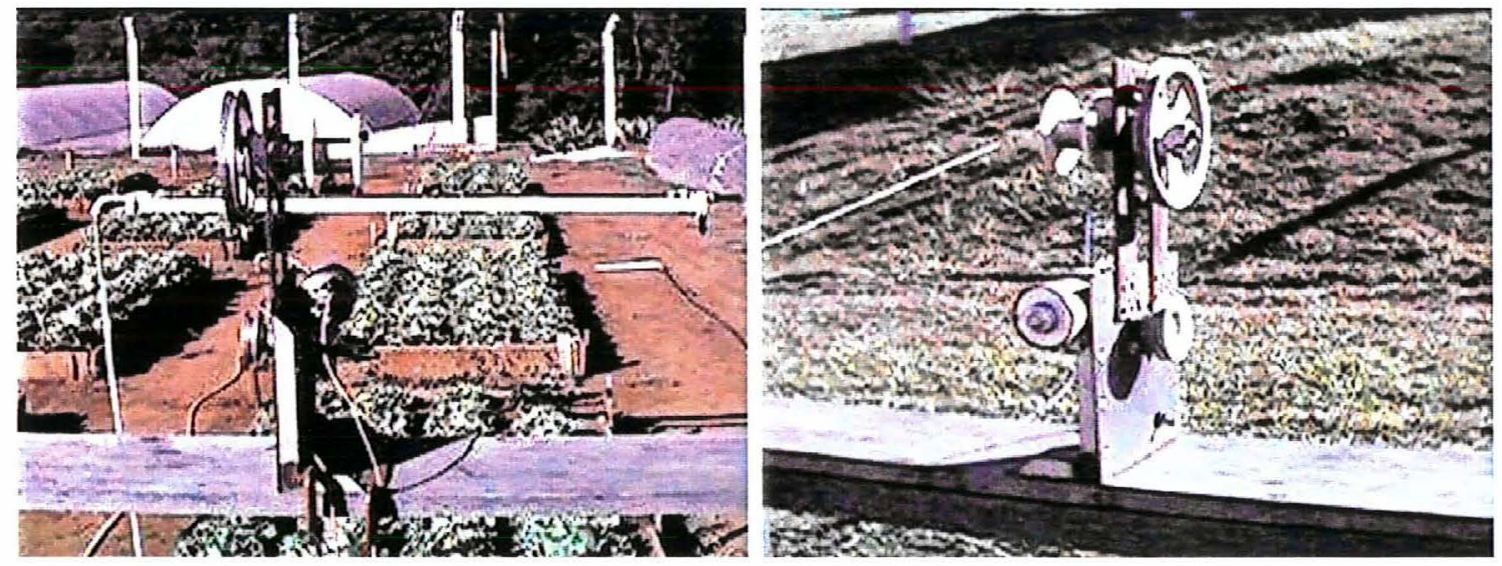

Figura 3 - Detalhes do sistema utilizado para tracionamento do carrinho com o tubo irrigador.

O motor foi parafusado em uma chapa de aço em forma de "L", cuja base foi fixada em uma bancada de madeira colocada junto aos dois mourões no início de cada fileira de canteiros.

Ao eixo do motor foi acoplada uma polia de $6,4 \mathrm{~cm}$, cuja rotação foi transmitida por uma correia de borracha para uma polia de $14,4 \mathrm{~cm}$, a qual foi fixado um eixo de ferro, onde na sua outra extremidade foi acoplado um carretel construído com tarugo de PVC, com um diâmetro de $3,6 \mathrm{~cm}$, na sua parte interna. 
A Figura 4 mostra o detalhe do carretel de PVC acoplado à polia maior do sistema de tracionamento do carrinho com o tubo irrigador.

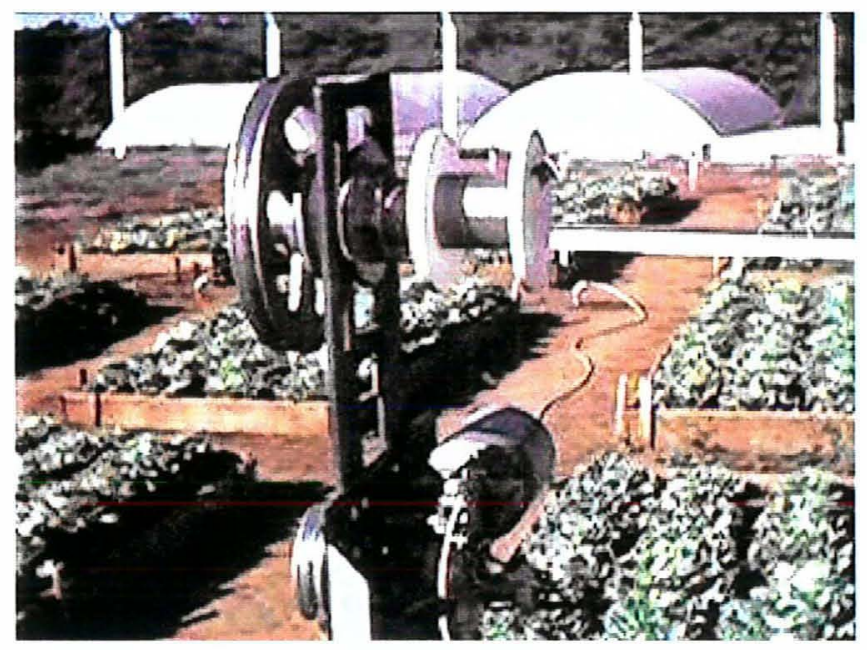

Figura 4 - Detalhe da colocação do carretel de PVC na polia do sistema de tracionamento do carrinho com o tubo irrigador.

Na parte interna do carretel, foi fixada a extremidade de um fino cabo de aço flexível com $0,50 \mathrm{~mm}$ de diâmetro. A outra extremidade foi presa no centro de um tirante feito com o mesmo material, e fixado nos extremos da parte anterior do carrinho com o tubo irrigador, o qual era colocado, antes do início da operação do sistema, na parte final de cada fileira de canteiros, para que pudesse ser tracionado quando do acionamento da chave liga/desliga do sistema de tracionamento.

O diâmetro da parte interna do carretel foi calculado para que quando o cabo de aço fosse enrolado em uma volta completa pelo perímetro interno do carretel, resultasse numa velocidade de deslocamento do carrinho que corresponderia à aplicação de uma lâmina de irrigação de cerca de 1,0 mm de altura, em cada passada do tubo irrigador sobre as fileira de canteiros. 
A alimentação de água ao sistema de irrigação foi feita por gravidade através de uma caixa d'água de $50 \ell$, situada a $150 \mathrm{~m}$ de distância em relação à área do experimento. O desnível geométrico do nível d'água na caixa d'água em relação ao local do experimento era de 5,65 m, o que resultou uma carga hidráulica na entrada do tubo irrigador, quando situado na parte final da primeira fileira de canteiros, e estando em repouso, equivalente a 5,0 m.c.a. .

A distribuição da água aos canteiros foi feita através de uma tubulação de PVC rígido, para instalação predial, de 20 mm (3/4") de diâmetro, enterrada na parte central das fileiras de canteiros, no sentido transversal ao seu comprimento, da qual saíram três hidrantes com a tomada d'água ficando a $15 \mathrm{~cm}$ acima da superfície do solo.

A tomada d'água, que alimentava individualmente cada uma das três fileiras de canteiros, era composta por um registro de esfera de $16 \mathrm{~mm}$ $\left(1 / 2^{\prime \prime}\right)$ e um engate rápido com saída fêmea. Neste engate rápido foi conectada a ponta macho da mangueira transparente e flexível, que conduziria a água até a entrada do tubo irrigador.

\subsection{Ensaio para determinação da vazão dos orifícios}

Após a montagem do tubo irrigador e antes de colocá-lo sobre o carrinho, realizou-se, no Laboratório de Hidráulica do Departamento de Engenharia Rural (ESALQ/USP), um ensaio para determinar-se a vazão de saída dos orifícios do tubo.

Para a realização do ensaio, construiu-se uma estrutura de madeira, a qual foi colocada sobre uma caixa de alvenaria para recepção da 
água proveniente de um canal de irrigação e condução para um reservatório, também em alvenaria, já existente no interior do laboratório.

O tubo irrigador, com os 24 orifícios, foi colocado sobre a estrutura de madeira.

$\mathrm{Na}$ extremidade de entrada do tubo irrigador foi conectada uma mangueira flexível de $20,0 \mathrm{~mm}$ (3/4") de diâmetro, que por sua vez estava acoplada à saída de uma tubulação ligada a um reservatório elevado, cujo nível de água é mantido constante a $15,0 \mathrm{~m}$ de altura, em relação ao piso do laboratório.

A regulagem da pressão foi feita através da abertura/fechamento do registro de gaveta de $20,0 \mathrm{~mm}\left(3 / 4^{\prime \prime}\right)$ instalado na entrada do tubo irrigador, e a medida da mesma foi realizada através das leituras de colunas líquidas de um manômetro em " $U$ ", tendo como líquido manométrico o mercúrio. O manômetro foi conectado à uma tomada de pressão instalada em uma luva de PVC de 20,0 mm (3/4") de diâmetro, logo após o registro de gaveta na entrada do tubo irrigador.

O ensaio consistiu na coleta do volume de água escoado por cada um dos 24 orifícios em um tempo de dois minutos, com a pressão de entrada no tubo irrigador regulada para 5,0 $\mathrm{m}$ de coluna d'água. A vazão foi determinada através da média obtida de três repetições para cada um dos orifícios.

Como a vazão média geral dos orifícios do tubo irrigador foi muito elevada, e como, também, verificou-se que o jato de saída dos orifícios era muito forte, o que poderia danificar as folhas de alface, é que optou-se por buscar outra alternativa para diminuição da vazão de saída dos orifícios. 
A solução encontrada foi a de usar-se agulhas descartáveis utilizadas em seringas de injeção, cujos conectores de plástico da agulha foram colados em peças de latão especialmente torneadas para esta finalidade, e soldadas em cada um dos 24 orifícios.

Testou-se três diferentes tipos de agulhas, a seguir relacionados:

- 20x5,5 - cor do conector: violeta, dimensões: $2,0 \mathrm{~cm}$ de comprimento da agulha por $0,55 \mathrm{~mm}$ de diâmetro

- 25x7,0 - cor do conector: preta, dimensões: $2,5 \mathrm{~cm}$ de comprimento da agulha por $0,70 \mathrm{~mm}$ de diâmetro

- 25x8,0 - cor do conector: verde, dimensões: $2,5 \mathrm{~cm}$ de comprimento da agulha por $0,80 \mathrm{~mm}$ de diâmetro

Realizou-se dois tipos de ensaios hidráulicos. O primeiro foi para a elaboração da curva característica de vazão vs. pressão, para cada um dos diferentes tipos de agulha, consistindo em coletar, em uma proveta graduada, num tempo de três minutos, o volume de água escoado pelos orifícios situados nas posições de números: 01, 06, 12, 18 e 24, a cinco diferentes pressões, a saber: 1,0 m.c.a. , 3,0 m.c.a. , 5,0 m.c.a. , 7,0 m.c.a. e 9,0 m.c.a. .

Em função da comparação entre as curvas de vazão vs. pressão dos três diferentes tipos de agulhas testados, selecionou-se o tipo de agulha mais adequado para atender as necessidades de aplicação da lâmina de irrigação durante a condução dos experimentos.

A seguir, realizou-se o segundo ensaio, que consistiu num teste de uniformidade de vazão para o tipo de agulha selecionado. O teste foi executado fixando-se uma pressão de 5,0 m.c.a. na entrada do tubo irrigador, e 
coletando-se em uma proveta graduada, num tempo de três minutos, o volume de água escoado por cada um dos 24 orifícios, para poder determinar-se a vazão de cada um deles.

Comparando-se a vazão de todos os orifícios, verificava-se em quais agulhas ocorria maior variação em relação à vazão média dos orifícios, providenciando-se a sua substituição por agulhas novas. O ensaio era repetido para este novo conjunto de agulhas, até que a dispersão entre as vazões fosse a menor possivel, o que foi confirmado quando atingiu-se um coeficiente de variação de vazão adequado.

\subsection{Construção dos canteiros}

Em função do planejamento adotado para o experimento, foram construídos 12 canteiros. A área ocupada por cada canteiro foi de $3,75 \mathrm{~m}^{2}$, com as dimensões de 1,25 m de largura, 3,00 m de comprimento e 0,20 m de altura, deixando-se um espaço de 1,20 m entre os canteiros e 1,50 m entre as fileiras de canteiros.

A Figura 5 ilustra a disposição dos canteiros na área experimental, com suas dimensões, e a distribuição, ao acaso, dos tratamentos de dose do produto para cada fileira de canteiros em seu respectivo tratamento de intervalo de irrigação, utilizados no primeiro experimento.

Cada canteiro foi cercado, ao redor de seu perímetro, por tábuas de madeira com $0,20 \mathrm{~m}$ de altura, tendo a finalidade de manter o solo incorporado com o produto confinado ao mesmo.

O experimento ocupou uma área total de $180,0 \mathrm{~m}^{2}(10,0 \times 18,0 \mathrm{~m})$. 


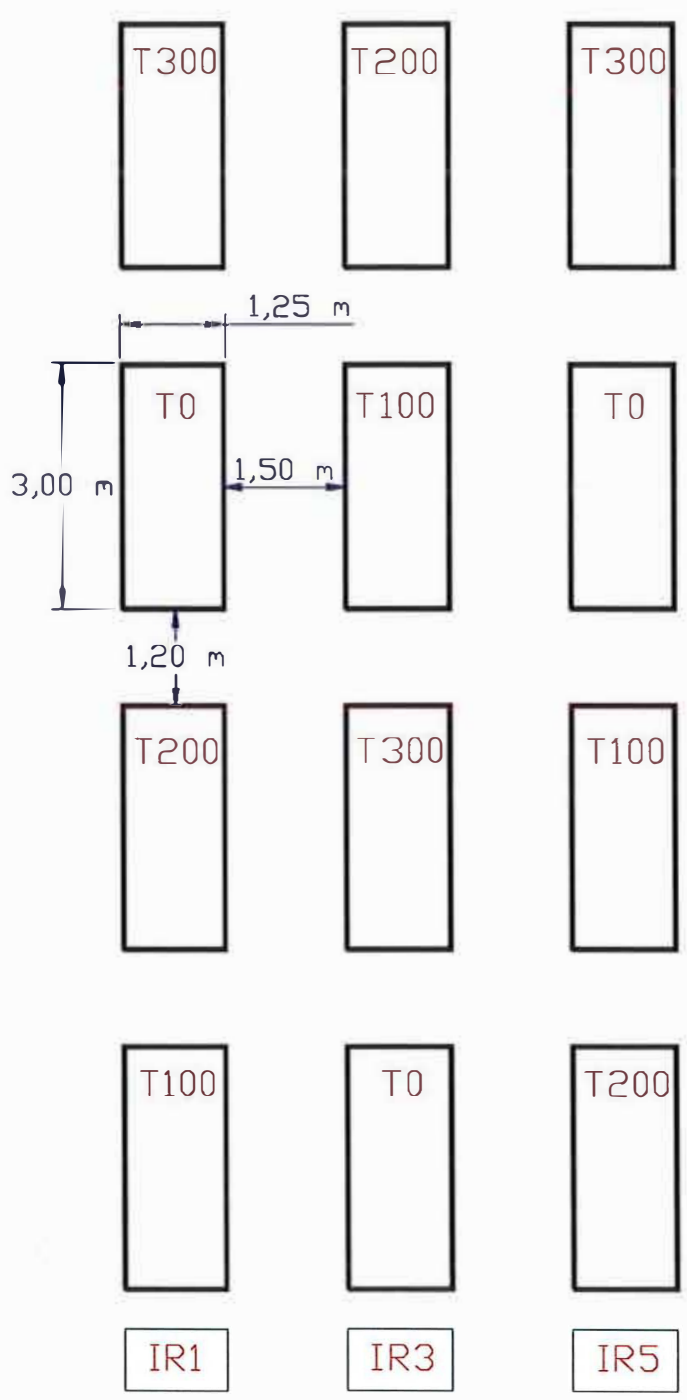

Figura 5 - Detalhes da disposição dos canteiros e distribuição dos tratamentos utilizados no primeiro experimento.

Antes da construção dos canteiros, foi realizada três meses antes do primeiro transplantio de mudas, uma adubação orgânica com húmus de minhoca na proporção de 120 t.ha ${ }^{-1}$, sendo incorporado ao solo com o auxílio de uma enxada. 


\subsection{Incorporação do produto ao solo}

Para que o polímero hidroretentor fosse incorporado ao solo de forma homogênea em todo o volume de solo dos 12 canteiros já previamente preparados, a uma determinada profundidade, empregou-se a metodologia descrita a seguir.

Como Filgueira (1982) e Blanco et al. (1997), relatam que o volume de solo explorado pelo sistema radicular da alface situa-se numa profundidade $25 \mathrm{~cm}$, pretendeu-se incorporar o produto a uma profundidade de $16 \mathrm{~cm}$, e sendo que cada canteiro formado possuía uma área de $3,75 \mathrm{~m}^{2}$, o volume de solo correspondente a cada canteiro foi de $0,600 \mathrm{~m}^{3}$.

Sendo assim, esse volume de solo foi retirado de cada canteiro com balde plástico graduado e com capacidade para $20,0 \ell$, formando-se, então, 12 montes de terra individuais com 600,0 $\ell$ cada.

Para que o produto fosse distribuído homogeneamente por todo 0 volume de solo de cada canteiro, utilizou-se uma betoneira de 150,0 $\ell$ de capacidade para misturar o produto ao solo.

Como o volume de solo a ser retornado em cada canteiro era o mesmo que foi retirado, ou seja, 600,0 $\ell$, usou-se, por vez, $120 \ell$ de solo a ser misturado com o produto na betoneira. Foram necessárias, então, 5 (cinco) cargas de solo a serem colocadas na betoneira para formar-se o volume total de solo em cada canteiro.

Para tentar minimizar o efeito do fator fertilidade do solo sobre os tratamentos a serem utilizados, retirou-se 10,0 $\ell$ de solo de cada um dos doze montes de terra reservados, para formar o volume de uma batida da betoneira. 
Uma vez que optou-se por este processo de incorporação do produto hidroretentor ao solo, aproveitou-se para incorporar em cada canteiro, também, o corretivo de acidez do solo, calculado em função dos resultados de análise química do solo apresentados na Tabela 1.

A calagem foi realizada dois meses antes do primeiro transplantio, na proporção de 1,34 t.ha-1 de calcário dolomítico, seguindo-se a recomendação de se elevar para $80 \%$ a saturação de bases (V\%) no solo. Juntamente com a correção da acidez do solo realizou-se a adubação química recomendada no transplantio da alface. Os valores determinados do corretivo e da adubação, para cada canteiro, foram divididos proporcionalmente para cada batida da betoneira.

O mesmo foi feito para os canteiros onde seriam aplicados os tratamentos com o produto hidroretentor, sendo colocada, em cada batida da betoneira, a quantidade proporcional do produto correspondente ao respectivo tratamento.

O tempo utilizado para efetuar a mistura do produto com o solo, juntamente com o corretivo e os adubos, foi de 10 minutos para cada batida da betoneira.

\subsection{Elaboração da curva de retenção de água do solo}

Alguns dias antes do início do plantio do segundo experimento, coletaram-se amostras indeformadas de solo dos canteiros para a elaboração da curva de retenção de água do solo. 
As amostras foram coletadas utilizando-se um percursor, onde na sua extremidade inferior foi encaixado um anel volumétrico com as seguintes dimensões médias: $2,92 \mathrm{~cm}$ de altura e $4,98 \mathrm{~cm}$ de diâmetro interno, representando um volume amostrado de solo de $56,88 \mathrm{~cm}^{3}$. O anel foi penetrado no solo através de batidas, com martelo de borracha, na extremidade superior do percursor.

Coletou-se uma amostra de cada um dos 12 (doze) canteiros do experimento, na camada de solo de $0-0,15 \mathrm{~m}$. Portanto, tivemos três amostras para cada um dos quatro tratamentos de dose do produto hidroretentor.

No laboratório, as amostras foram manipuladas seguindo-se o padrão recomendado para sua preparação. Nesta etapa, descartou-se uma das amostras coletadas nos canteiros do tratamento T200, pois no seu preparo o volume de solo amostrado ficou menor que o volume do anel.

As amostras, após saturadas, foram colocadas, inicialmente, em uma mesa de tensão (funil de Haines), sendo, então, submetidas às tensões equivalentes a $-1,0 \mathrm{kPa},-2,0 \mathrm{kPa},-4,0 \mathrm{kPa}$ e $-10,0 \mathrm{kPa}$. Posteriormente, essas amostras foram colocadas em câmaras de pressão (com placas ou membranas porosas), onde foram submetidas às tensões equivalentes a $-30,0 \mathrm{kPa}$, $-50,0 \mathrm{kPa},-100,0 \mathrm{kPa},-500 \mathrm{kPa}$ e $-1500 \mathrm{kPa}$.

Os valores do teor de umidade do solo, com base em peso seco, obtidos após a aplicação das tensões acima referidas, para cada um dos canteiros, foram ajustados ao modelo proposto por Van Genuchten (1980) através do programa computacional Soil Water Retention Curve (SWRC), versão 2.0 (Dourado Neto, 1996), conforme eq. (1) mostrada a seguir: 


$$
\mathrm{U}=\mathrm{U}_{\mathrm{r}}+\frac{\left(\mathrm{U}_{\mathrm{S}}-\mathrm{U}_{\mathrm{r}}\right)}{\left[1+\left(\alpha \cdot \phi_{\mathrm{m}}\right)^{\mathrm{n}}\right]^{\mathrm{m}}}
$$

onde:

U, Us e Ur, representam a umidade gravimétrica, umidade gravimétrica de saturação e umidade gravimétrica residual (obtida à $1500 \mathrm{kPa}$ ), respectivamente;

$\phi_{\mathrm{m}}$, potencial mátrico do solo, em kPa;

$\alpha, \mathrm{m}$ e $\mathrm{n}$, representam parâmetros que dependem do solo.

\subsection{Manejo de irrigação}

Para que o manejo de irrigação de uma cultura seja efetuado de forma racional, é necessário, dentre outros fatores, que a evapotranspiração de referência (ETo) seja estimada por um método que apresente uma menor variação de erro, quando comparado a métodos lisimétricos, em uma determinada região.

Saad \& Scaloppi (1988), apresentaram um estudo para avaliação de onze métodos climatológicos na estimativa da evapotranspiração de referência, onde o método combinado de Penman-Monteith forneceu melhores resultados, seguido pelos métodos de Jensen-Haise e da Radiação.

Entretanto, Stanhill (1961) observando a precisão, os custos envolvidos, o tempo gasto em leituras, considera o tanque Classe A como o método mais indicado para a determinação da evapotranspiração a nível de campo.

Como um dos objetivos deste trabalho foi propor uma alternativa de manejo para o produtor de alface, é que utilizamos o método do tanque 
Classe A para estimativa da evapotranspiração de referência (ETo), que de acordo com Doorembos \& Kassan (1979), é obtida através da relação:

$$
\text { Eto }=\mathrm{Eca} \cdot \mathrm{kp}_{\mathrm{p}}
$$

sendo:

Eca, a evaporação do tanque Classe $A$, em mm.dia ${ }^{-1}$, e $k_{p}$, um coeficiente de conversão de evaporação do tanque Classe A em evapotranspiração de referência.

coeficiente $k_{p}$ foi estimado pela equação proposta por Snyder (1992):

$$
k_{p}=0,482+0,024 \operatorname{Ln}(F)-0,000376 U_{2}+0,0045 U R
$$

onde:

F , distância da área de bordadura (área vegetal) em volta do tanque, em $\mathrm{m}$;

$\mathrm{U}_{2}$, velocidade média do vento a $2,0 \mathrm{~m}$ de altura, em $\mathrm{km} . \mathrm{d}^{-1}$; UR, umidade relativa média diária (\%).

A evapotranspiração da cultura (ETc) foi determinada através da multiplicação do valor estimado da evapotranspiração de referência (ETo) por um coeficiente admensional, denominado coeficiente de cultura $\left(k_{c}\right)$, sendo dado pela razão entre a evapotranspiração máxima de uma cultura (ETm), cultivada sem restrições de água, e a evapotranspiração de referência (ETo). 
Bastos (1994), determinou os coeficientes de cultivo $\left(k_{c}\right)$ para diversas fases fenológicas da alface, através do método do tanque Classe $A$, cujos valores utilizados para o manejo de irrigação, são mostrados a seguir:

- Fase II (do transplantio aos 16 dias seguintes): $k_{c}=0,50$;

- Fase III (do final da fase anterior aos 37 dias após o transplantio: $k_{c}=0,80$;

- Fase IV (do final da fase anterior até a colheita): $k_{c}=0,90$.

O manejo de irrigação iniciou-se uma semana após o transplantio das mudas de alface.

Para a determinação da necessidade de irrigação, utilizou-se de uma planilha de cálculo, onde com os dados climáticos do dia anterior era estimada a evapotranspiração da cultura (ETc) e descontada a precipitação, caso ocorresse, para o cálculo da lâmina de irrigação a ser aplicada aos canteiros.

$\mathrm{Na}$ fileira de canteiros do tratamento de intervalo de irrigação de um dia (IR1), a lâmina de irrigação foi dividida pela lâmina de 0,90 mm, estimada como aquela a ser aplicada pelo carrinho com o tubo irrigador em sua passagem pelo canteiro, para determinar-se o número de passagens a serem dadas pelo carrinho nesta fileira de canteiros.

Para os tratamentos de intervalo de irrigação de três dias (IR3) e de cinco dias (IR5), a lâmina de irrigação foi determinada somando-se a diferença entre a evapotranspiração da cultura e a precipitação ocorrida, nos últimos três dias e cinco dias, respectivamente. Para o cálculo do número de passagens do carrinho, por cada respectiva fileira de canteiros, utilizou-se o mesmo procedimento adotado para o tratamento IR1. 


\subsection{Condução da cultura}

\subsubsection{Primeiro experimento}

A adubação mineral dos canteiros, no primeiro experimento, foi realizada conjuntamente ao processo de incorporação do produto hidroretentor ao solo.

A adubação foi feita com base na análise química de solo (Tabela 1), seguindo-se a recomendação de Blanco et al. (1997), que teve como fonte Raij et al. (1992), e constou da proporção de 40 kg/ha de N , 400 $\mathrm{kg} / \mathrm{ha}$ de $\mathrm{P}_{2} \mathrm{O}_{5}, 50 \mathrm{~kg} / \mathrm{ha}$ de $\mathrm{K}_{2} \mathrm{O}$ e $1,0 \mathrm{~kg} / \mathrm{ha}$ de $\mathrm{B}$. Como fonte de $\mathrm{N}, \mathrm{P}, \mathrm{K}$ e B foram usados, respectivamente, uréia, superfosfato simples, cloreto de potássio e ácido bórico.

Dois meses após o término da operação de homogeneização do solo, já misturado com o produto hidroretentor, os adubos e o corretivo de acidez, e retorno aos respectivos canteiros, sendo o nivelamento da superfície do solo realizado com uma enxada e um rastelo, realizou-se o transplantio das mudas de alface no dia 04/11/1999.

A variedade de alface utilizada foi a Tainá, pertencente ao grupo de folhas crocantes (tipo "crisp-head") ou americana, por apresentarem folhas crocantes e grossas com fechamento de cabeça, sendo mais resistentes ao pendoamento floral durante a estação do verão.

As mudas foram produzidas por viveirista da região e formadas em bandejas de isopor de 12 × 24 células, sendo transplantadas com cerca de um mês após a semeadura e tendo de 2 a 3 pares de folhas. 
Para o estabelecimento das mudas nos canteiros, procedeu-se à aplicação de água através da mangueira utilizada em cada um dos três pontos de tomada d'água das fileiras de canteiros. A água era aplicada na parte da manhã e no final da tarde, até que visualmente a superfície do solo parecia bem molhada.

Durante esta fase de estabelecimento das mudas, houve um desenvolvimento bastante uniforme das plantas, sendo que apenas duas morreram, dentre o total de 480 mudas plantadas nos canteiros.

Dez dias após o transplantio, iniciaram-se os tratamentos em relação ao fator irrigação. Houve possibilidade de adotar-se o manejo de irrigação da cultura em apenas uma semana e meia, pois a partir daí iniciou-se um período de chuvas, não permitindo mais a utilização da irrigação até a fase de colheita da cultura.

A adubação em cobertura foi feita aplicando-se $75 \mathrm{~kg} / \mathrm{ha}$ de $\mathrm{N}$, na forma de uréia, parcelada em três vezes, aos 10, 20 e 30 dias após o transplante.

As ervas daninhas que cresciam nos canteiros foram controladas através de capinas manuais, realizadas periodicamente.

Durante o acompanhamento do desenvolvimento das plantas, observou-se a presença de mosquinha branca (Bemifia argentifolli), provocando uma espécie de enrugamento no limbo das folhas. Para controle desta praga, uso-se o inseticida com principio ativo Acefat, na dosagem de 0,4 kg. ha ${ }^{-1}$, fazendo-se duas aplicações semanais com um pulverizador costal, até que a população dos insetos diminuisse. 
Observou-se, também, a presença de pulgões em um número razoável de plantas a ocorrência de trípes, que uma vez infectando algumas plantas com vírus, resultou na doença denominada por vira-cabeça.

\subsubsection{Segundo experimento}

Antes do início do plantio do segundo experimento, realizou-se uma amostragem de solo para a determinação das características físicas do solo, em relação à sua textura, efetuando-se uma análise granulométrica, seguindo-se o procedimento do método da pipeta.

As amostras foram compostas obtendo-se uma porção de solo da camada superficial $(0-0,15 \mathrm{~m})$ de cada uma das parcelas das três fileiras de canteiros, correspondentes a cada respectivo tratamento, e misturando-as para formar uma amostra de cada tratamento relativo à dose do produto hidroretentor.

Esta análise foi realizada no Laboratório de Solos do Departamento de Engenharia Rural (ESALQ/USP), cujo resultado é mostrado na Tabela 2.

Também, dessa amostragem, foram retiradas amostras de solo para cada respectivo tratamento de dose do produto hidroretentor, enviando-as ao Laboratório de Solos do Departamento de Solos e Nutrição de Plantas da ESALQ/USP, para análise química de solo, e cujo resultado encontra-se na Tabela 3. 
Tabela 2. Análise granulométrica determinada para cada respectivo tratamento de dose do produto hidroretentor.

\begin{tabular}{cccc}
\hline & Areia & Silte & Argila \\
\cline { 2 - 4 } Tratamento & $(\%)$ & $(\%)$ & $(\%)$ \\
\hline T0 & 37,38 & 20,45 & 42,17 \\
T100 & 37,54 & 21,85 & 40,61 \\
T200 & 36,35 & 23,71 & 39,94 \\
T300 & 40,95 & 19,73 & 39,32 \\
\hline
\end{tabular}

Tabela 3. Análise química de solo para cada respectivo tratamento de dose do produto hidroretentor.

\begin{tabular}{|c|c|c|c|c|c|c|c|c|c|c|c|}
\hline \multirow{2}{*}{ Trat. } & & & & K & $\mathrm{Ca}$ & $\mathrm{Mg}$ & $\mathrm{H}+\mathrm{Al}$ & $S B$ & \multirow[t]{2}{*}{$T_{0}$} & \multirow{2}{*}{$\begin{array}{l}\text { V } \\
\%\end{array}$} & \multirow{2}{*}{$\begin{array}{c}B \\
\mathrm{mg} \cdot \mathrm{dm}^{-3}\end{array}$} \\
\hline & $\left(\mathrm{CaCl}_{2}\right)$ & g. $\cdot \mathrm{dm}^{-3}$ & $\mathrm{mg} \cdot \mathrm{dm}^{-3}$ & \multicolumn{5}{|c|}{$\mathrm{mmol}_{\mathrm{c}} \cdot \mathrm{dm}^{-3}$} & & & \\
\hline TO & 6,1 & 20 & 80 & 4,3 & 54 & 21 & 16 & 79,3 & 95,3 & 83 & 0,54 \\
\hline T100 & 6,2 & 22 & 85 & 4,3 & 57 & 21 & 15 & 82,3 & 97,3 & 85 & 0,73 \\
\hline T200 & 5,9 & 25 & 76 & 4,8 & 61 & 24 & 18 & 89,8 & 107,8 & 83 & 0,60 \\
\hline T300 & 5,9 & 21 & 63 & 5,0 & 54 & 21 & 16 & 80,0 & 96,0 & 83 & 0,60 \\
\hline
\end{tabular}

A adubação foi realizada com base na análise química de solo (Tabela 3), seguindo-se a mesma recomendação de Blanco et al. (1997), e constou da proporção de $40 \mathrm{~kg} / \mathrm{ha}$ de $\mathrm{N}, 200 \mathrm{~kg} / \mathrm{ha}$ de $\mathrm{P}_{2} \mathrm{O}_{5}, 50 \mathrm{~kg} / \mathrm{ha}$ de $\mathrm{K}_{2} \mathrm{O}$ e $1,0 \mathrm{~kg} / \mathrm{ha}$ de $\mathrm{B}$. Como fonte de N, P, K e B foram usados, respectivamente, uréia, superfosfato simples, cloreto de potássio e ácido bórico. 
Uma semana após a adubação dos canteiros, no dia 30/03/2000, foi realizado o transplantio das mudas de alface, da mesma variedade, a Tainá, utilizada no experimento anterior.

Para o estabelecimento das mudas de alface na sua fase inicial, foi utilizado o mesmo procedimento adotado no primeiro experimento. O manejo de irrigação foi iniciado dez dias após o transplantio das mudas.

A adubação em cobertura foi feita da mesma forma que aquela realizada no experimento anterior, como quantidade de $\mathrm{N}$ e intervalo de tempo entre as aplicações.

As ervas daninhas que cresciam nos canteiros foram controladas através de capinas manuais, realizadas periodicamente. As pragas e doenças observadas neste experimento foram as mesmas descritas no experimento anterior.

Uma vista geral do segundo experimento é mostrada na Figura 6.

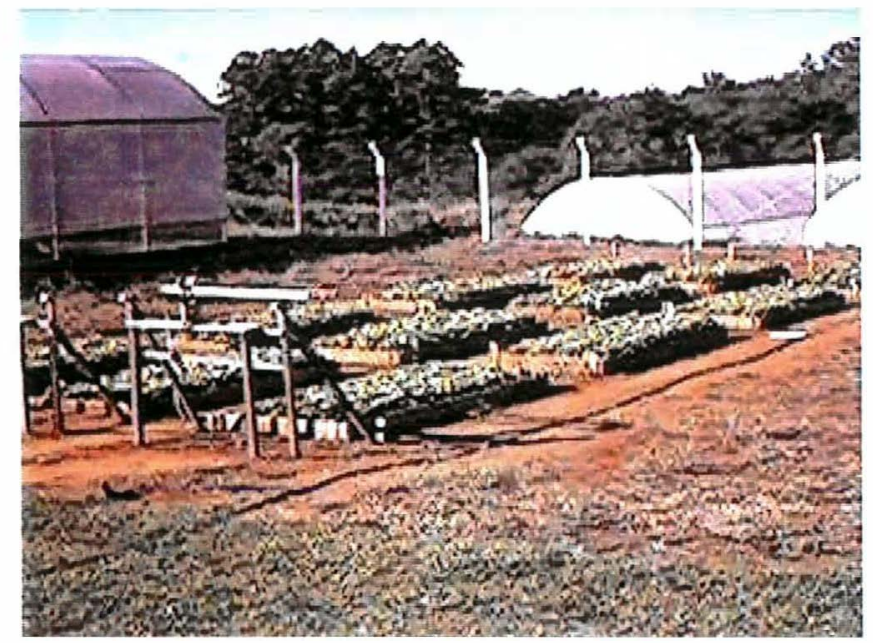

Figura 6 - Vista geral dos canteiros de alface no segundo experimento. 


\subsubsection{Terceiro experimento}

A adubação do terceiro experimento foi realizada na mesma proporção de dosagem e fontes de N, P e K, daquelas utilizadas no segundo experimento.

Uma semana após a adubação dos canteiros, no dia 15/06/2000, foi realizado o transplantio das mudas de alface, da mesma variedade, a Tainá, utilizada nos experimentos anteriores.

Para o estabelecimento das mudas de alface na sua fase inicial, foi utilizado o mesmo procedimento adotado nos outros dois experimentos. $O$ manejo de irrigação foi iniciado dez dias após o transplantio das mudas.

A adubação em cobertura foi feita da mesma forma que aquela realizada nos experimentos anteriores, como quantidade de $\mathrm{N}$ e intervalo de tempo entre as aplicações.

As ervas daninhas que cresciam nos canteiros foram controladas através de capinas manuais, realizadas periodicamente.

Neste experimento houve uma maior dificuldade no controle da presença da mosquinha branca e de trípes, como descritas para os experimentos anteriores, ocorrendo um maior número de plantas afetadas pelos sintomas respectivos.

Esta ocorrência era esperada em razão da recomendação de não se plantar cultivos sucessivos de alface na mesma área. Porém, em virtude do prazo para conclusão do trabalho, não foi possivel fazer rotação de culturas entre os plantios de alface. 


\section{RESULTADOS E DISCUSSÃO}

\subsection{Teste de vazão dos orifícios do tubo irrigador}

No ensaio efetuado com o tubo irrigador com orifícios de $1,0 \mathrm{~mm}$ de diâmetro, verificou-se que, com uma pressão de entrada de 5,0 m.c.a., a vazão média geral dos 24 orifícios foi de 19,20 I. $\mathrm{h}^{-1}$, com um desvio padrão de $2,70 \mathrm{I} \cdot \mathrm{h}^{-1}$. Também observou-se que a vazão de alguns orifícios foi bem inferior em relação à vazão média, o que poderia ser justificado pela imperfeição no processo manual de perfuração dos orifícios no tubo de cobre, resultando na presença de rebarbas na saída dos orifícios.

Por esta razão, e principalmente pelo fato da vazão média geral dos orifícios ser muito elevada em relação à lâmina de irrigação a ser aplicada na condução do experimento, é que buscou-se a alternativa na utilização de agulhas descartáveis de seringas de injeção.

Para os três diferentes tipos de agulhas descartáveis testados, ajustou-se uma curva do tipo potencial aos dados obtidos no ensaio realizado para determinação da curva vazão vs. pressão, cujas equações com seus coeficientes de determinação são mostradas a seguir:

$$
\begin{array}{lll}
\text { Agulha Verde 8.0: } & q=1,676 \cdot h^{0,594}, & r^{2}=0,9994 \\
\text { Agulha Preta 7.0: } & q=0,869 \cdot h^{0,669}, & r^{2}=0,9979 \\
\text { Agulha Rosa 5.5: } & q=0,320 \cdot h^{0,632}, & r^{2}=0,9984
\end{array}
$$


onde:

$q=$ vazão do orifício da agulha, em $I \cdot h^{-1}$

$\mathrm{h}=$ pressão na entrada do tubo irrigador, em m.c.a.

Estas curvas são apresentadas na Figura 7.

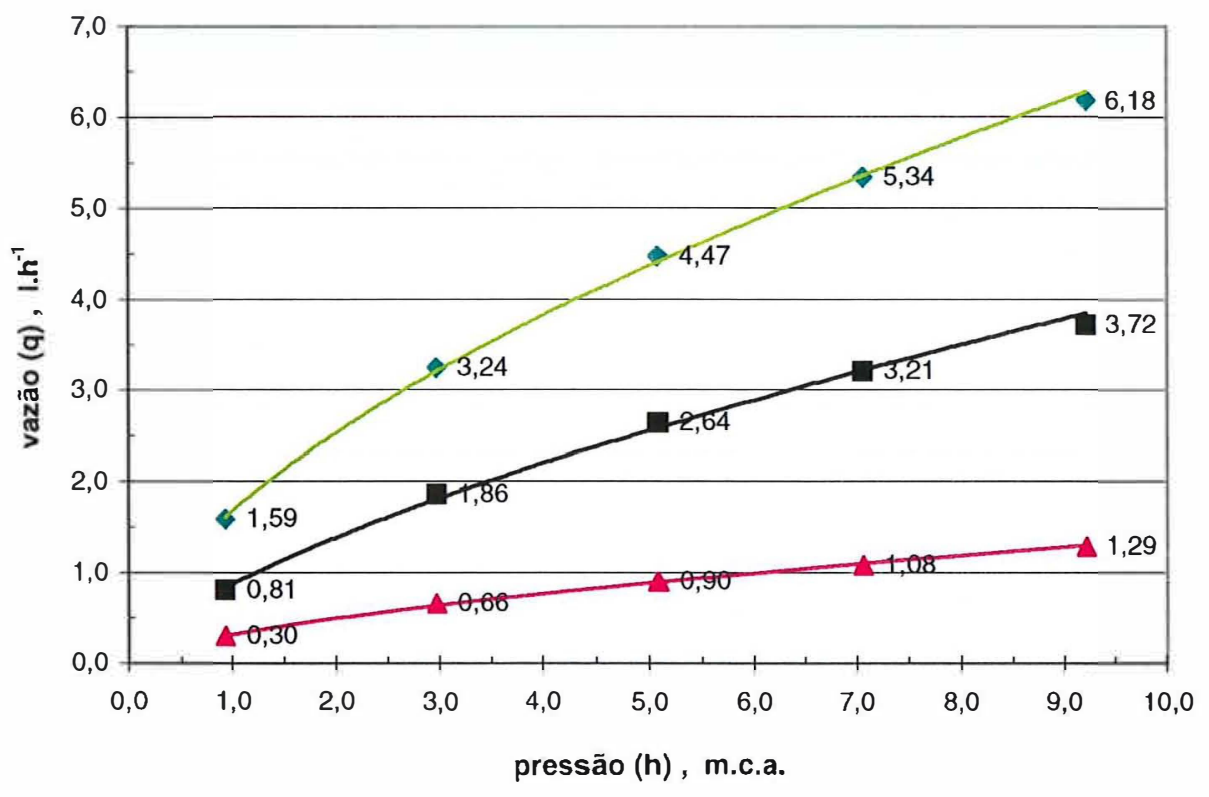

\section{— Agulha 8.0 - Agulha 7.0 - Agulha 5.5}

Figura 7 - Curva vazão vs. pressão determinada para os três tipos de agulhas descartáveis testados.

Em função dos resultados obtidos no ensaio com os três tipos de agulhas descartáveis testados, selecionou-se a agulha de conector plástico verde (orifício 8.0), pois apresentou uma vazão em torno de 4,4 I. $\mathrm{h}^{-1}$ para uma pressão de entrada no tubo irrigador de 5,0 m.c.a., que além de ser superior à dos outros dois tipos de agulhas, é também mais compatível com a lâmina de irrigação a ser utilizada na condução dos experimentos. 
Uma vez definida a agulha a ser utilizada, realizou-se novo ensaio para determinação da curva vazão vs. pressão, coletando-se o volume de água das agulhas situadas nas posições de números 01, 06, 12, 18 e 24 do tubo irrigador, agora com o intervalo de pressão de entrada entre 0,5 a 5,0 m.c.a. .

A curva obtida, juntamente com a equação e o coeficiente de determinação, é mostrada na Figura 8.

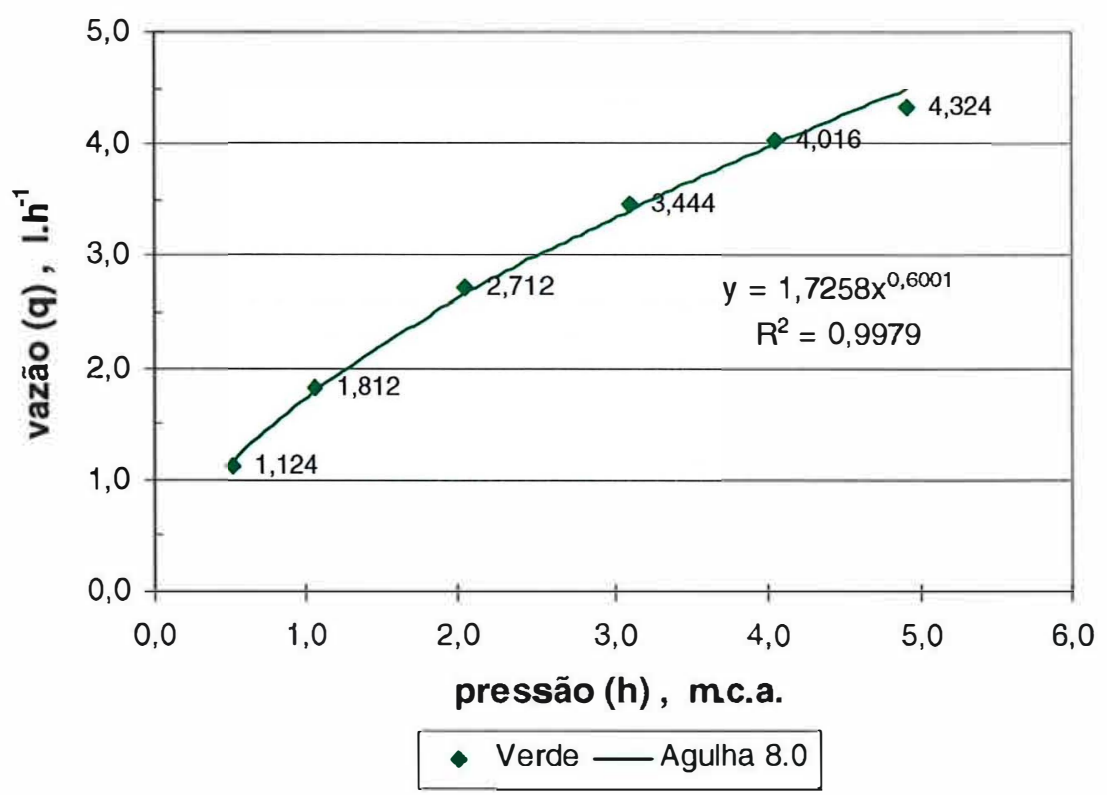

Figura 8 - Curva vazão vs. pressão obtida para a agulha descartável verde, no segundo ensaio.

Comparando-se as equações obtidas nos dois ensaios, verifica-se uma grande aproximação entre os coeficientes determinados para o ajuste dos dados observados através de uma equação do tipo potencial. Assim, podemos considerar esta equação como característica da relação vazão vs. pressão para este tipo de agulha selecionado. 
Como o valor do expoente de emissão obtido $(x=0,600)$ está dentro do intervalo de 0,5 a 0,7, segundo Keller \& Karmeli (1974), o seu fluxo é considerado parcialmente turbulento e instável.

O teste de uniformidade de vazão realizado, onde coletou-se 0 volume de água escoado na saída dos 24 orifícios das agulhas, quando a pressão de entrada no tubo irrigador era de 5,0 m.c.a., revelou uma vazão média dos orifícios de 4,32 I. $\mathrm{h}^{-1}$, com um desvio padrão de 0,48 $1 . \mathrm{h}^{-1}$ e um coeficiente de variação de $11,2 \%$. Se não considerarmos a vazão de quatro orifícios, que tiveram uma vazão discrepante em relação à média, a vazão passaria a ser de $4,441 . h^{-1}$, com um coeficiente de variação de 3,2 \% .

Por este motivo, as agulhas com vazões muito diferentes em relação à média foram substituídas por agulhas novas, e realizado novo teste de uniformidade, até chegar-se ao resultado da vazão média dos orifícios ser igual a 4,45 I. $\mathrm{h}^{-1}$, com um desvio padrão de 0,18 I. $\mathrm{h}^{-1}$ e um coeficiente de variação igual a 4,04 \% .

Um mês antes do início do primeiro experimento, instalou-se o tubo irrigador, já montado no carrinho, em uma das estruturas de trilhos de arame, onde o mesmo seria tracionado ao longo de uma das fileiras de canteiros.

Para verificar-se a uniformidade de vazão dos orifícios das agulhas, em condições de campo, realizaram-se novos testes de uniformidade. Foram necessários mais sete testes para que, com a substituição daquelas agulhas com vazões discrepantes em relação à média do respectivo ensaio, fosse atingida a vazão média dos orifícios igual a $4,175 \mathrm{I} \cdot \mathrm{h}^{-1}$, com um desvio padrão de 0,151 I. $h^{-1}$ e um coeficiente de variação de 3,62 \% . 
Assim, com este valor de vazão média dos orifícios, considerou-se como sendo a vazão do tubo irrigador igual a $100,21 \cdot h^{-1}$, a qual foi utilizada para cálculo da lâmina de irrigação aplicada aos canteiros, em função da velocidade de deslocamento do carrinho.

\subsection{Curva de retenção de água}

Os resultados dos valores de densidade do solo, calculados para as amostras indeformadas de solo coletadas nos canteiros de cada respectivo tratamento de dose do produto hidroretentor, são apresentados na Tabela 4.

Tabela 4. Resultados dos valores de densidade do solo, calculados para cada fileira de canteiros nos respectivos tratamentos de dose do produto.

\begin{tabular}{cccc}
\hline & \multicolumn{3}{c}{$\begin{array}{c}\text { Densidade do solo } \\
\left(\mathrm{g} . \mathrm{cm}^{-3}\right)\end{array}$} \\
\cline { 2 - 4 } Tratamento & \multicolumn{3}{c}{ Intervalo de Irrigação } \\
\cline { 2 - 4 } IR1 & IR3 & IR5 \\
\hline T0 & 1,50 & 1,40 & 1,41 \\
T100 & 1,20 & 1,29 & 1,29 \\
T200 & 1,44 & - & 1,41 \\
T300 & 1,28 & 1,43 & 1,37 \\
\hline
\end{tabular}

A Figura 9 representa graficamente as curvas de retenção de água, elaboradas para as amostras coletadas nos canteiros referentes a cada respectivo tratamento de dose do produto hidroretentor. Os valores de umidade gravimétrica, determinados em função das diversas tensões aplicadas, foram ajustados ao modelo proposto por Van Genuchten (1980). 

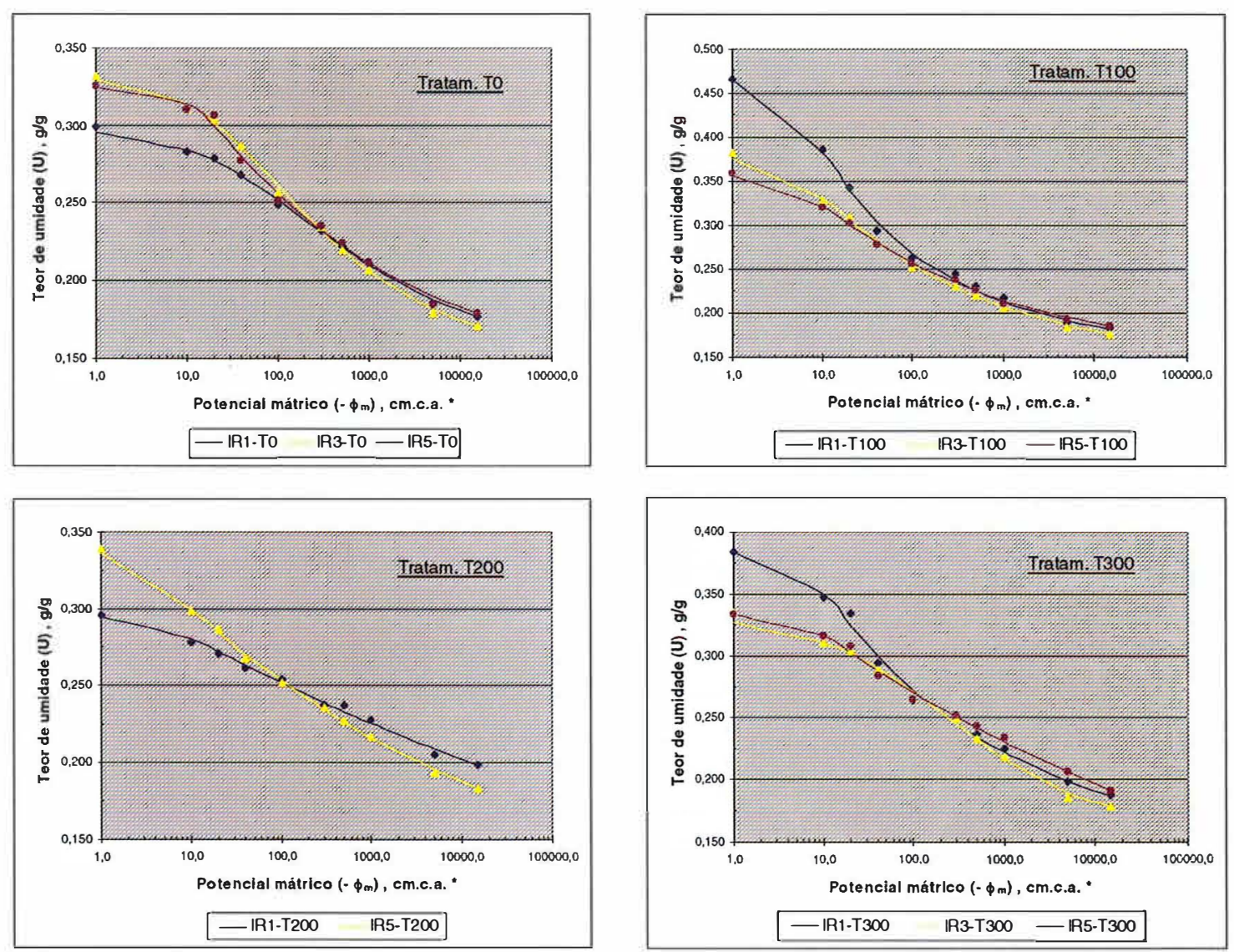

* 1,0 cm.c.a $\approx 0,1 \mathrm{kPa}$

Figura 9 - Curvas de retenção de água no solo, para os respectivos tratamentos de dose do produto hidroretentor.

Como uma das amostras coletadas com o anel volumétrico foi descartada para a elaboração da curva de retenção de água do solo, também não se determinou a densidade do solo para esta amostra, portanto, obteve-se apenas dois valores de densidade do solo para o tratamento T200 (Tabela 4).

Por este motivo, para se ter uma curva de retenção de água do solo representativa para cada tratamento de dose do produto, tirou-se a média de dois valores de umidade gravimétrica obtidos para cada respectiva tensão aplicada, tendo-se como critério, para escolha das curvas, aquelas que tiveram 
os valores de densidade do solo mais próximos para cada respectivo tratamento.

Pode-se observar na Figura 9 que, nas amostras onde houve uma diferença maior na densidade do solo, em cada respectivo tratamento de dose do produto, as curvas de retenção ficaram mais afastadas entre si no intervalo de tensão entre 1,0 a 100,0 cm.c.a. , o que equivale a 0,1 a 10,0 kPa.

As curvas de retenção de água do solo obtidas através da média dos valores de duas amostras, para cada respectivo tratamento de dose do produto hidroretentor, e ajustadas pelo modelo de Van Genuchten (1980), são mostradas na Figura 10.

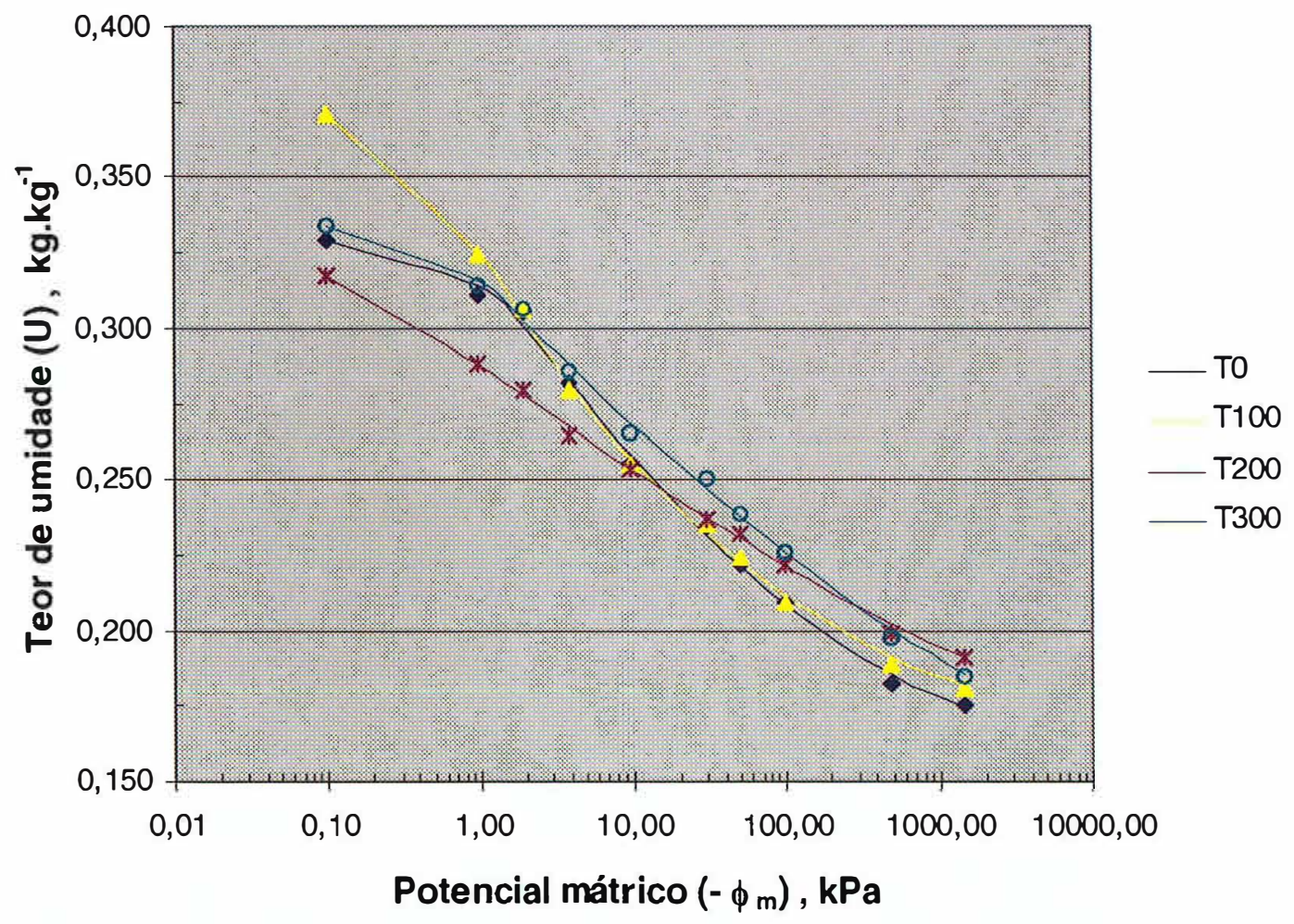

Figura 10 - Curvas de retenção de água do solo representativas para cada tratamento de dose do produto hidroretentor. 
Observando-se as curvas de retenção de água do solo da Figura 10, verifica-se que a partir do potencial mátrico de $-10,0 \mathrm{kPa}$ há um efeito mais claro no aumento do teor de umidade do solo, em base gravimétrica, em função de doses crescentes do produto hidroretentor.

A partir daquele valor de potencial mátrico, há pouca variação no teor de umidade do solo entre os tratamentos T0 e T100, mas para o tratamento T300 ocorreu um maior aumento no teor de umidade do solo, principalmente, no intervalo de potencial mátrico entre $-10,0 \mathrm{kPa}$ e $-100,0 \mathrm{kPa}$.

Reichardt (1988), afirma que a capacidade de campo é o resultado de um comportamento dinâmico da água no perfil de solo, e não uma característica intrínseca de sua matriz. Variações nas condições iniciais e de contorno do processo de drenagem interna levam a valores distintos de capacidade de campo.

Neste artigo, o autor comenta que profissionais interessados em irrigação poderão determiná-la dois a três dias após o processo de molhamento do solo, quando o intervalo de irrigação é menor do que dez dias, e recomenda que, utilizando-se de métodos de laboratório para sua determinação, dever-seia optar por potenciais mátricos maiores, da ordem de $-10,0$ a $-6,0 \mathrm{kPa}$, que ocorrem com maior freqüência em solos submetidos à drenagem em condições de campo.

Se adotarmos $-10,0 \mathrm{kPa}$ para representar o teor de umidade do solo na capacidade de campo, ou mesmo o valor clássico de $-33,0 \mathrm{kPa}$, verificamos na Tabela 5 que, embora houvesse aumento no teor de umidade, este não foi muito sensível às doses do produto utilizadas neste trabalho, mesmo quando comparamos tratamentos extremos, isto é, testemunha (TO) com o de maior dose (T300). 
Tabela 5. Valores do teor de umidade do solo ( $\left.U_{c c}\right)$, em base gravimétrica, e de lâmina de água $\left(h_{c c}\right)$, em três diferentes tensões de água no solo, para os tratamentos de dose do produto hidroretentor.

\begin{tabular}{lcccccc}
\hline Trat. & $\begin{array}{c}U_{\mathrm{cc}} \\
(\mathrm{g} / \mathrm{g})\end{array}$ & $\begin{array}{c}\mathrm{h}_{\mathrm{cc}} \\
(\mathrm{mm} / \mathrm{cm})\end{array}$ & $\begin{array}{c}\mathrm{U}_{\mathrm{cc}} \\
(\mathrm{g} / \mathrm{g})\end{array}$ & $\begin{array}{c}\mathrm{h}_{\mathrm{cc}} \\
(\mathrm{mm} / \mathrm{cm})\end{array}$ & $\begin{array}{c}\mathrm{U}_{100} \\
(\mathrm{~g} / \mathrm{g})\end{array}$ & $\begin{array}{c}\mathrm{h}_{100} \\
(\mathrm{~mm} / \mathrm{cm})\end{array}$ \\
\cline { 2 - 7 } & \multicolumn{1}{c}{$10,0 \mathrm{kPa}$} & \multicolumn{2}{c}{$33,0 \mathrm{kPa}$} & \multicolumn{2}{c}{$100,0 \mathrm{kPa}$} \\
\hline T0 & 0,258 & 3,62 & 0,229 & 3,22 & 0,208 & 2,92 \\
T100 & 0,256 & 3,30 & 0,230 & 2,97 & 0,211 & 2,72 \\
T200 & 0,253 & 3,61 & 0,236 & 3,36 & 0,221 & 3,15 \\
T300 & 0,268 & 3,75 & 0,245 & 3,43 & 0,225 & 3,15 \\
\hline
\end{tabular}

\subsection{Análise dos experimentos}

\subsubsection{Primeiro experimento}

O primeiro experimento (cultivo de verão) teve um ciclo de 42 dias até o início da colheita.

As condições climáticas presentes nesta época do ano fazem com que 0 ciclo de cultivo seja curto. Podemos observar, na Tabela 6 , os dados climáticos médios ocorridos durante o desenvolvimento da cultura da alface.

Na Figura 11 é mostrada a seqüência dos valores de evaporação do tanque classe $A$ (Eca); de evapotranspiração de referência (ETo), estimada pelo método do tanque classe $A$; de evapotranspiração da cultura (ETC), e os eventos de precipitação diária (Prec.) ocorridos durante o ciclo da cultura. 
Tabela 6. Dados climáticos registrados durante o ciclo de cultivo da alface no primeiro experimento.

\begin{tabular}{lrrrrrrrrr}
\hline & $\begin{array}{l}\text { Prec. } \\
(\mathrm{mm})\end{array}$ & $\begin{array}{c}\text { Evap. } \\
(\mathrm{mm} / \mathrm{d})\end{array}$ & $\begin{array}{c}\text { R.G. } \\
\left(\mathrm{MJ} / \mathrm{m}^{2} . \mathrm{d}\right)\end{array}$ & $\begin{array}{c}\text { Ins. } \\
(\mathrm{h} / \mathrm{d})\end{array}$ & $\begin{array}{l}\text { U.R. } \\
(\%)\end{array}$ & $\begin{array}{c}\text { Ven. } \\
(\mathrm{km} / \mathrm{h})\end{array}$ & $\begin{array}{c}\text { T.mx. } \\
\left({ }^{\circ} \mathrm{C}\right)\end{array}$ & $\begin{array}{c}\text { T.mn. } \\
\left({ }^{\circ} \mathrm{C}\right)\end{array}$ & $\begin{array}{r}\text { T.md. } \\
\left({ }^{\circ} \mathrm{C}\right)\end{array}$ \\
\hline Média & 5,4 & 5,88 & 19,14 & 6,4 & 76,0 & 9,7 & 29,5 & 17,0 & 23,2 \\
Desv. Padrão & 11,4 & 1,36 & 6,42 & 4,1 & 12,0 & 3,5 & 3,5 & 2,4 & 2,0 \\
Valor máx. & 48,2 & 9,04 & 29,26 & 12,0 & 99,0 & 20,6 & 35,4 & 20,8 & 26,0 \\
Valor mín. & 0,0 & 2,50 & 6,52 & 0,0 & 52,0 & 4,7 & 19,5 & 12,3 & 17,4 \\
Total & 226,6 & 246,77 & - & - & - & - & - & - & - \\
Dias de chuva & 21 & - & - & - & - & - & - & - & - \\
\hline
\end{tabular}

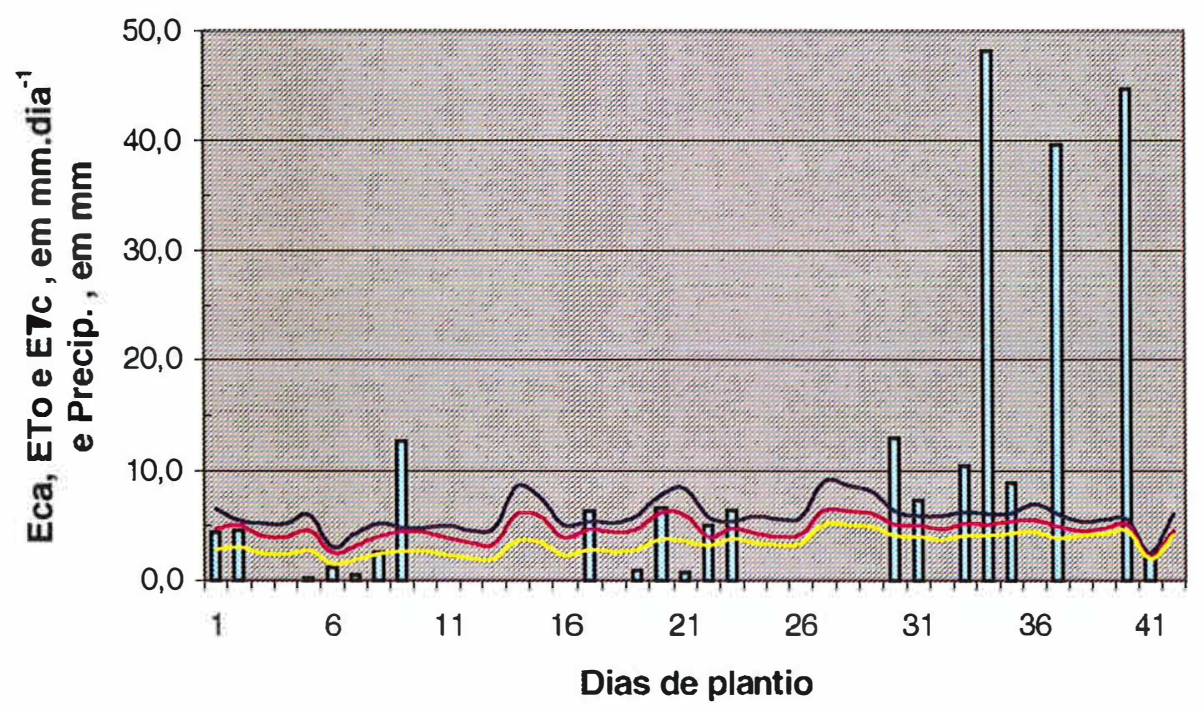

ĐPrecip. -Eca -ETo - ETc

Figura 11 - Seqüência dos valores registrados de evaporação do tanque Classe A (Eca), evapotranspiração de referência (ETo), evapotranspiração da cultura (ETc) e eventos de precipitação diária (Prec.), ocorridos durante o primeiro experimento. 
Como nos tratamentos de irrigação estabeleceu-se um intervalo máximo de irrigação de cinco dias, se considerarmos a precipitação acumulada neste intervalo de tempo, ou seja, por pêntadas, e compararmos com a evapotranspiração da cultura no mesmo período, verificamos que apenas na terceira pêntada não ocorreu precipitação (Figura 12).

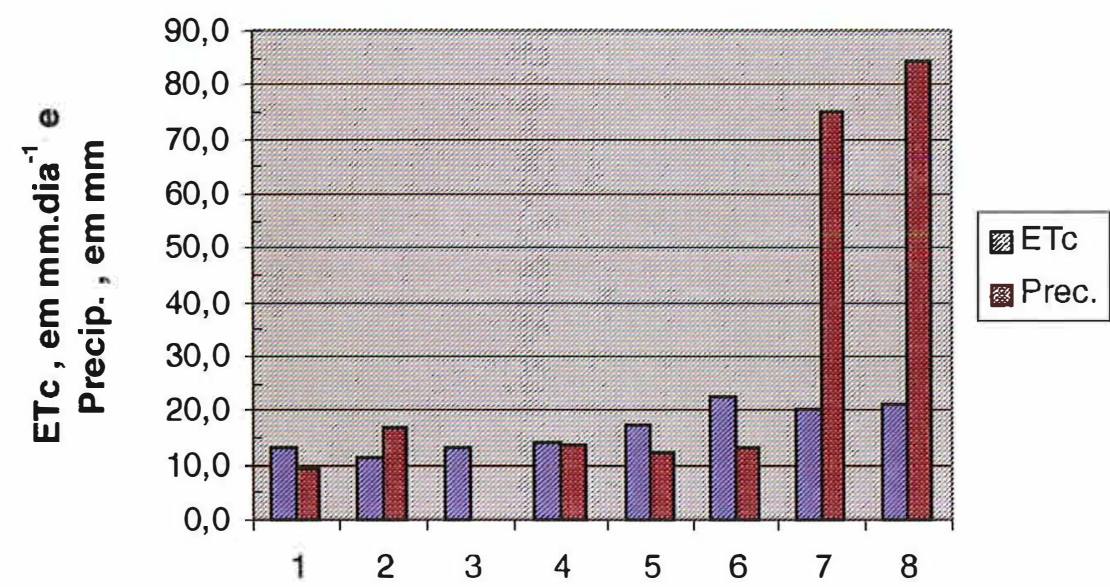

Pêntadas

Figura 12 - Comparação, em pêntadas, entre a evapotranspiração da cultura e a precipitação ocorridas durante o primeiro experimento.

Em termos de manejo de irrigação, os primeiros dez dias após o transplantio das mudas de alface foram para o estabelecimento da cultura, irrigando-se, através da mangueira flexível, todos os canteiros do experimento sem um controle efetivo da lâmina aplicada.

Na terceira pêntada, como não houve precipitação, irrigou-se com 6 passadas, através do carrinho com o tubo irrigador, a fileira de canteiros com o tratamento IR1, o que correspondeu à uma lâmina estimada de 5,4 mm. A fileira de canteiros com o tratamento IR3 foi irrigada com 9 passadas, correspondendo à uma lâmina estimada de $8,1 \mathrm{~mm}$, e a fileira de canteiros com 
o tratamento IR5 foi irrigada com 15 passadas, correspondendo à uma lâmina estimada de $13,5 \mathrm{~mm}$.

A precipitação aproximou-se da evapotranspiração da cultura, nas pêntadas seguintes, ocorrendo, nos últimos 13 (treze) dias do ciclo da cultura, um aumento significativo na freqüência e magnitude da precipitação, o que praticamente não permitiu a continuidade do manejo de irrigação neste experimento.

Portanto, na análise estatística dos dados de produção obtidos neste experimento não foi considerado o efeito do fator intervalo de irrigação.

A colheita foi realizada em dois dias, nas fileiras de canteiros correspondentes aos tratamentos IR3 e IR5.

As variáveis dependentes medidas para avaliação do experimento foram: peso fresco da planta (PF), matéria seca (MS), peso da cabeça da alface $(P C)$, distância longitudinal da projeção da planta (DL), distância transversal da projeção da planta (DT) e número de folhas (NF).

A análise de variância, para o conjunto de 55 observações, realizada através do programa computacional Statistical Analysis System (SAS), com o procedimento ANOVA, levando-se em conta o modelo do efeito de dose do produto hidroretentor, revelou ser não significativa, ao nível de $5 \%$ de probalidade, para as variáveis dependentes analisadas, exceto para a variável dependente distância transversal (DT), que foi significativa ao nível de $1 \%$ de probabilidade.

As médias das variáveis analisadas para os tratamentos de dose do produto hidroretentor são mostradas na Tabela 7. 
Tabela 7. Valores das médias das variáveis avaliadas no primeiro experimento.

\begin{tabular}{lccccccc}
\hline Trat. & $\begin{array}{c}\text { Número } \\
\text { de plantas }\end{array}$ & $\begin{array}{c}\text { PF } \\
(\mathrm{g})\end{array}$ & $\begin{array}{c}\mathrm{MS} \\
(\mathrm{g})\end{array}$ & $\begin{array}{c}\mathrm{PC} \\
(\mathrm{g})\end{array}$ & $\begin{array}{c}\mathrm{DL} \\
(\mathrm{cm})\end{array}$ & $\begin{array}{c}\text { DT } \\
(\mathrm{cm})\end{array}$ & NF \\
\hline T0 & 13 & 403,4 & 15,8 & 227,6 & 34,9 & 35,1 & 8,0 \\
T100 & 11 & 351,7 & 14,1 & 201,4 & 33,8 & 31,2 & 7,2 \\
T200 & 15 & 400,3 & 17,2 & 218,4 & 34,4 & 34,7 & 8,3 \\
T300 & 16 & 429,1 & 16,1 & 254,4 & 34,8 & 35,2 & 7,1 \\
\hline
\end{tabular}

Considerando a matéria seca (MS) o parâmetro que caracteriza o ganho de massa pela planta, vemos que os tratamentos T200 e T300, que receberam a maior dose do produto, tiveram as maiores médias. No geral, observou-se que o tratamento T100 foi o que teve a menor média em relação a quase todas as variáveis analisadas.

Para a comparação de médias entre os tratamentos de dose do produto hidroretentor utilizou-se o teste de múltiplo intervalo de Duncan, onde obteve-se o seguinte resultado:

- para a variável PF, a média do tratamento T300 diferiu estatisticamente da média do T100;

- para a variável MS, a média do tratamento T200 diferiu estatisticamente da média do T100;

- para as variáveis PC e DL não houve diferença estatística entre as médias dos tratamentos;

- para a variável DT, as médias dos tratamentos T300, T0 e T200 foram diferentes estatisticamente da média do T100;

- para a variável NF, a média do tratamento T200 diferiu estatisticamente da média do T300. 
Em razão do tempo despendido nas medições das diversas variáveis envolvidas durante a colheita, o primeiro experimento norteou-nos a fazer algumas simplificações na avaliação dos outros dois experimentos, decidindo-se obter apenas o peso fresco (PF) e a matéria seca (MS) das plantas de alface.

\subsubsection{Segundo experimento}

O segundo experimento (cultivo de outono) teve um ciclo de 47 dias até o início da colheita.

A fase de colheita durou dez dias, iniciando-se no dia 16/05/2000 e encerrando-se no dia 25/05/2000.

Podemos observar, na Tabela 8 , os dados climáticos médios ocorridos durante o desenvolvimento da cultura da alface.

Tabela 8. Dados climáticos registrados durante o ciclo de cultivo da alface no segundo experimento.

\begin{tabular}{lccccccccc}
\hline & $\begin{array}{l}\text { Prec. } \\
(\mathrm{mm})\end{array}$ & $\begin{array}{c}\text { Evap. } \\
(\mathrm{mm} / \mathrm{d})\end{array}$ & $\begin{array}{c}\text { R.G. } \\
\left(\mathrm{MJ} / \mathrm{m}^{2} . \mathrm{d}\right)\end{array}$ & $\begin{array}{l}\text { Ins. } \\
(\mathrm{h} / \mathrm{d})\end{array}$ & $\begin{array}{c}\text { U.R. } \\
(\%)\end{array}$ & $\begin{array}{c}\text { Ven. } \\
(\mathrm{km} / \mathrm{h})\end{array}$ & $\begin{array}{c}\text { T.mx. } \\
\left({ }^{\circ} \mathrm{C}\right)\end{array}$ & $\begin{array}{c}\text { T.mn. } \\
\left({ }^{\circ} \mathrm{C}\right)\end{array}$ & $\begin{array}{c}\text { T.md. } \\
\left({ }^{\circ} \mathrm{C}\right)\end{array}$ \\
\hline Média & 0,74 & 3,84 & 17,58 & 8,45 & 73,94 & 6,24 & 28,80 & 14,11 & 21,45 \\
Desv. Padrão & 0,23 & 0,85 & 3,02 & 2,43 & 6,57 & 2,77 & 2,41 & 2,61 & 2,17 \\
Valor máx. & 1,10 & 5,56 & 22,11 & 11,10 & 92,00 & 14,20 & 32,60 & 18,40 & 24,85 \\
Valor mín. & 0,00 & 1,93 & 9,28 & 0,30 & 63,00 & 1,30 & 23,60 & 9,00 & 17,00 \\
Total & 3,70 & 180,26 & - & - & - & - & - & - & - \\
Dias de chuva & 5 & - & - & - & - & - & - & - & - \\
\hline
\end{tabular}


Na Figura 13 é mostrada a seqüência dos valores de evaporação do tanque classe $A$ (Eca); de evapotranspiração de referência (ETo), estimada pelo método do tanque classe $A$; de evapotranspiração da cultura (ETc), e os eventos de precipitação diária (Prec.) ocorridos durante o ciclo da cultura.

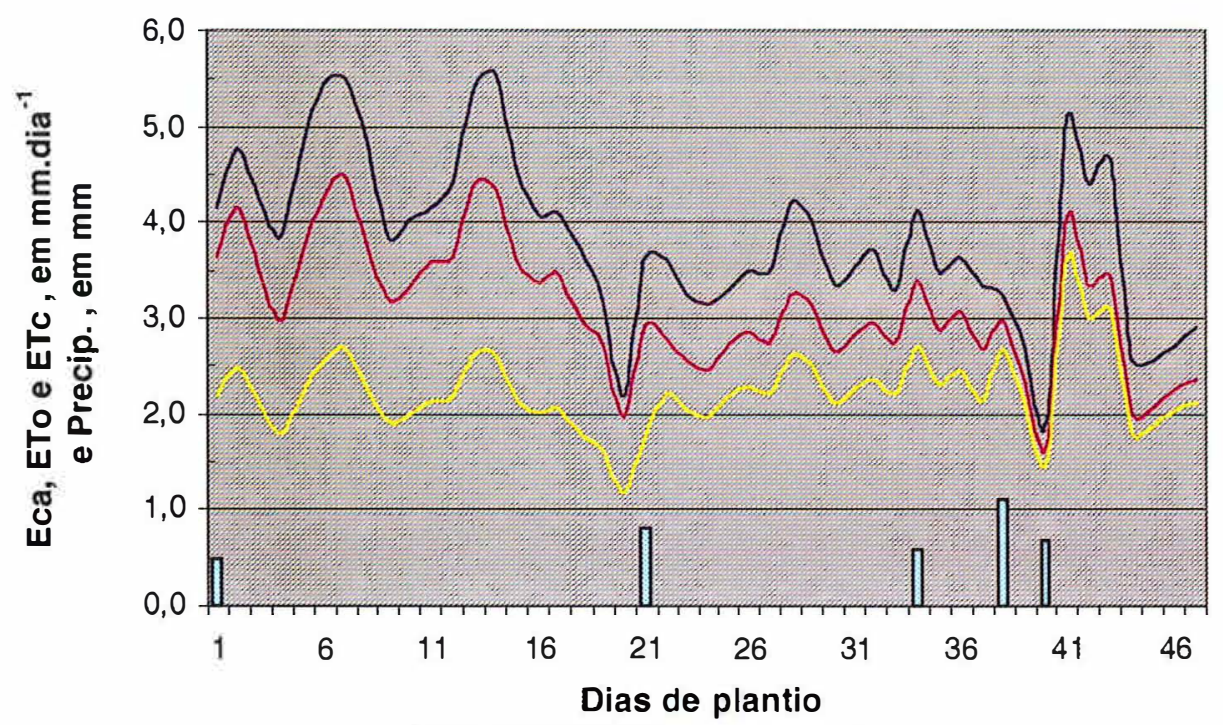

$\square$ Precip. —Eca - ETo ETc

Figura 13 - Seqüência dos valores registrados de evaporação do tanque Classe A (Eca), evapotranspiração de referência (ETo), evapotranspiração da cultura (ETc) e eventos de precipitação diária (Prec.), ocorridos durante o segundo experimento.

Através de uma planilha de cálculo desenvolvida para o controle do manejo de irrigação dos experimentos, determinaram-se, para todo o ciclo de cultivo da alface, os valores acumulados da evaporação do tanque Classe $A$ $\left(E_{C A}=180,3 \mathrm{~mm}\right)$, da evapotranspiração de referência $\left(E T_{O}=146,2 \mathrm{~mm}\right)$ e da evapotranspiração da cultura (ETC $=104,8 \mathrm{~mm})$. 
Com estes valores, verificou-se que o coeficiente médio do tanque Classe $A\left(k_{p}\right)$ utilizado durante o ciclo de desenvolvimento da cultura da alface foi de 0,81 . Já o valor do coeficiente médio de cultivo $\left(k_{c}\right)$, determinado para o período correspondente ao transplantio das mudas até o final da fase anterior à colheita, foi de 0,72 .

Para certificar-se que a lâmina de irrigação aplicada aos canteiros atendeu as necessidades de consumo de água das plantas durante o seu ciclo de desenvolvimento, determinou-se a lâmina total aplicada em cada tratamento de dose do produto hidroretentor, em seu respectivo tratamento de intervalo de irrigação (Tabela 9), e comparando-se com o valor da evapotranspiração da cultura acumulada no período de irrigação $(70,95 \mathrm{~mm})$ e o valor do total de precipitação ocorrida no mesmo período $(3,20 \mathrm{~mm})$.

Tabela 9. Valores de lâmina total de irrigação aplicadas aos diferentes tratamentos no segundo experimento.

\begin{tabular}{cccc}
\hline \multirow{2}{*}{ Tratamento } & \multicolumn{3}{c}{$\begin{array}{c}\text { lâmina de irrigação } \\
(\mathrm{mm})\end{array}$} \\
\cline { 2 - 4 } & IR1 & IR3 & IR5 \\
\hline T0 & 74,56 & 66,54 & 68,65 \\
T100 & 72,73 & 70,00 & 70,29 \\
T200 & 71,50 & 69,96 & 68,05 \\
T300 & 74,68 & 68,68 & 68,75 \\
\hline
\end{tabular}

As variáveis dependentes avaliadas no experimento foram o peso fresco da planta (PF) e a matéria seca (MS). 
A análise de variância, para o conjunto de 471 dados da variável peso fresco (PF) e 183 dados da variável matéria seca (MS), realizada através do programa computacional SAS, usando-se o procedimento General Linear Models (GLM), e tendo-se como modelo o efeito do fator dose do produto hidroretentor e o efeito do fator intervalo de irrigação, revelou ser significativa a interação entre os fatores estudados, ao nível de $1 \%$ de probabilidade, para as variáveis dependentes analisadas.

As médias das variáveis peso fresco (PF) e matéria seca (MS), para os tratamentos respectivos, são mostradas na Tabela 10.

Tabela 10. Valores médios obtidos para as variáveis peso fresco (PF) e matéria seca (MS), em cada tratamento de dose do produto (DOSE), para os respectivos intervalos de irrigação (INTER), no segundo experimento.

\begin{tabular}{lccc}
\hline DOSE & INTER & $\begin{array}{c}\text { PF } \\
(\mathrm{g})\end{array}$ & $\begin{array}{c}\text { MS } \\
(\mathrm{g})\end{array}$ \\
\hline T0 & IR1 & 365,6 & 10,7 \\
T0 & IR3 & 273,0 & 9,8 \\
T0 & IR5 & 352,2 & 10,9 \\
T100 & IR1 & 415,8 & 12,8 \\
T100 & IR3 & 438,9 & 13,3 \\
T100 & IR5 & 280,2 & 11,3 \\
T200 & IR1 & 287,8 & 10,8 \\
T200 & IR3 & 481,0 & 12,9 \\
T200 & IR5 & 363,3 & 10,6 \\
T300 & IR1 & 468,0 & 10,9 \\
T300 & IR3 & 416,6 & 11,9 \\
T300 & IR5 & 477,4 & 14,8 \\
\hline
\end{tabular}


Para a comparação de médias entre os tratamentos, utilizou-se o procedimento GLM do programa SAS, para médias de quadrados mínimos, ajustadas para comparações múltiplas de Tukey-Kramer, onde obteve-se o seguinte:

a) variável peso fresco

Os resultados para a variável peso fresco (PF), quando da interação entre os tratamentos de dose do produto hidroretentor com os tratamentos de intervalo de irrigação, são mostrados na Tabela 11.

Tabela 11. Resultado da análise de comparação de médias para a variável peso fresco (PF), no segundo experimento.

\begin{tabular}{llll}
\hline \multirow{2}{*}{ Tratamento } & \multicolumn{3}{c}{ Intervalo de Irrigação } \\
\cline { 2 - 4 } & \multicolumn{1}{c}{ IR1 } & \multicolumn{1}{c}{ IR3 } & \multicolumn{1}{c}{ IR5 } \\
\hline T0 & 365,6 a B & 273,0 b B & 352,2 a B \\
T100 & 415,8 a AB & 438,9 a A & 280,2 b C \\
T200 & 287,8 c C & 481,0 a A & 363,3 b B \\
T300 & 468,0 a A & 416,6 a A & 477,4 a A \\
\hline
\end{tabular}

Médias de intervalo de irrigação (IR) para a variável peso fresco (PF), seguidas de mesma letra minúscula (linha), não diferem entre si pelo teste de TukeyKramer ao nível de 0,05 de significância e médias de doses do produto (T) para a variável peso fresco (PF), seguidas de mesma letra maiúscula (coluna), não diferem entre si pelo mesmo teste e significância.

Analisando-se o efeito do fator intervalo de irrigação (IR), dentro de cada dose do produto, verificou-se que:

- para o tratamento de dose T0, IR1 e IR5 diferiram estatisticamente de IR3; 
- para o tratamento de dose T100, IR3 e IR1 diferiram estatisticamente de IR5;

- para o tratamento de dose T200, IR3 diferiu estatisticamente de IR5 e IR1, e IR5 diferiu de IR1;

- para o tratamento de dose T300, não houve diferença estatística entre as médias de IR5, IR1 e IR3.

Analisando-se o efeito do fator dose do produto $(T)$, dentro de cada intervalo de irrigação, verificou-se que:

- para o tratamento intervalo de irrigação IR1, o tratamento T300 diferiu estatisticamente de T0 e T200, embora não tenha diferido de T100;

- para o tratamento intervalo de irrigação IR3, os tratamentos T200, T100 e T300 diferiram estatisticamente de T0;

- para o tratamento intervalo de irrigação IR5, o tratamento T300 diferiu estatisticamente dos demais, e os tratamentos T200 e T0 diferiram de T100.

Com estes resultados, podemos inferir que, em relação à variação do intervalo de irrigação dentro de cada dose do produto, o esperado seria que o tratamento sem o produto (T0) tivesse um decréscimo da média da variável peso fresco (PF) com o aumento do intervalo de irrigação. Embora, isto não tenha ocorrido, IR1 teve a maior média, apesar de não ser estatisticamente diferente de IR5.

Para o tratamento com a maior dose do produto (T300), o esperado seria que com o possivel aumento da capacidade de retenção de água do solo com a incorporação do polímero hidroretentor, o tratamento com maior intervalo de irrigação (IR5) pudesse ter um resultado parecido com o 
tratamento IR1, o que de fato aconteceu, pois o tratamento IR5 teve a maior média da variável peso fresco (PF), embora não diferisse estatisticamente em relação aos outros tratamentos.

Também, observou-se que houve um aumento da média entre os tratamentos de intervalo de irrigação, para um aumento da dose do produto.

Em relação à variação da dose do produto dentro de cada intervalo de irrigação, verificou-se que o tratamento T300 esteve sempre entre aqueles tratamentos de maior média, que não diferiram estatisticamente entre si, principalmente dentro do tratamento IR5 onde sua média foi maior, diferindo estatisticamente dos outros tratamentos de dose do produto.

Com estas considerações, uma vez que não houve diferença significativa entre as médias da variável peso fresco (PF) entre os intervalos de irrigação adotados, para a maior dose do produto (T300), e que para o intervalo de irrigação de 5 dias o tratamento T300 foi o que teve a maior média para o peso fresco (PF), poder-se-ia sugerir como uma estratégia de manejo de irrigação a ser adotada, vindo de encontro à hipótese formulada neste trabalho.

b) variável matéria seca

Os resultados para a variável matéria seca (MS), quando da interação entre os tratamentos de dose do produto hidroretentor com os tratamentos de intervalo de irrigação, são mostrados na Tabela 12.

Analisando-se o efeito do fator intervalo de irrigação (IR), dentro de cada dose do produto, verificou-se que: 
- para os tratamentos de doses do produto T0, T100 e T200, não houve diferença estatística entre as médias dos tratamentos de intervalo de irrigação (IR);

- para o tratamento de dose T300, o IR5 diferiu estatisticamente de IR1.

Analisando-se o efeito do fator dose do produto $(T)$, dentro de cada intervalo de irrigação, verificou-se que:

- para os tratamentos de intervalo de irrigação IR1 e IR3, não houve diferença estatística entre as médias dos tratamentos de dose do produto (T);

- para o tratamento de intervalo de irrigação IR5, o T300 diferiu estatisticamente de TO e T200.

Tabela 12. Resultado da análise de comparação de médias para a variável matéria seca (MS), no segundo experimento.

\begin{tabular}{cccc}
\hline \multirow{2}{*}{ Tratamento } & \multicolumn{3}{c}{ Intervalo de Irrigação } \\
\cline { 2 - 4 } & IR1 & \multicolumn{1}{c}{ IR3 } & \multicolumn{1}{c}{ IR5 } \\
\hline T0 & 10,7 a A & 9,8 a A & 10,9 a B \\
T100 & 12,8 a A & 13,3 a A & 11,3 a AB \\
T200 & 10,8 a A & 12,9 a A & 10,6 a B \\
T300 & 10,9 b A & 11,9 ab A & 14,8 a A \\
\hline
\end{tabular}

Médias de intervalo de irrigação (IR) para a variável matéria seca (MS), seguidas de mesma letra minúscula (linha), não diferem entre si pelo teste de TukeyKramer ao nível de 0,05 de significância e médias de doses do produto (T) para a variável matéria seca (MS), seguidas de mesma letra maiúscula (coluna), não diferem entre si pelo mesmo teste e significância. 
Em relação à variação do intervalo de irrigação dentro de cada dose do produto, para o tratamento dose do produto T300, apesar de IR5 ter diferido estatisticamente de IR1, foi o tratamento que teve a maior média da variável analisada. Também, em relação à variação da dose do produto dentro de cada intervalo de irrigação, para o intervalo de irrigação de 5 dias (IR5), o tratamento T300, embora não diferisse estatisticamente de T100, teve a maior média em comparação com os outros tratamentos.

\subsubsection{Terceiro experimento}

O terceiro experimento (cultivo de inverno) teve um ciclo de 68 dias até o início da colheita.

A fase da colheita durou nove dias, iniciando-se no dia 23/08/2000 e encerrando-se no dia 31/08/2000.

Podemos observar, na Tabela 13, os dados climáticos médios ocorridos durante o desenvolvimento da cultura de alface.

Na Figura 14 é mostrada a evolução dos valores de evaporação do tanque classe $A$ (Eca), de evapotranspiração de referência (ETo), estimada pelo método do tanque classe $A$, de evapotranspiração da cultura (ETc), e os eventos de precipitação diária (Prec.) ocorridos durante o ciclo da cultura.

As variáveis dependentes avaliadas no experimento foram o peso fresco da planta (PF) e a matéria seca (MS). 
Tabela 13. Dados climáticos registrados durante o ciclo de cultivo da alface, no terceiro experimento.

\begin{tabular}{lccccccccc}
\hline & $\begin{array}{l}\text { Prec. } \\
(\mathrm{mm})\end{array}$ & $\begin{array}{c}\text { Evap. } \\
(\mathrm{mm} / \mathrm{d})\end{array}$ & $\begin{array}{c}\text { R.G. } \\
\left(\mathrm{MJ} / \mathrm{m}^{2} . \mathrm{d}\right)\end{array}$ & $\begin{array}{l}\text { Ins. } \\
(\mathrm{h} / \mathrm{d})\end{array}$ & $\begin{array}{c}\text { U.R. } \\
(\%)\end{array}$ & $\begin{array}{c}\text { Ven. } \\
(\mathrm{km} / \mathrm{h})\end{array}$ & $\begin{array}{c}\text { T.mx. } \\
\left({ }^{\circ} \mathrm{C}\right)\end{array}$ & $\begin{array}{c}\text { T.mn. } \\
\left({ }^{\circ} \mathrm{C}\right)\end{array}$ & $\begin{array}{c}\text { T.md. } \\
\left({ }^{\circ} \mathrm{C}\right)\end{array}$ \\
\hline Média & 1,33 & 3,14 & 13,30 & 6,22 & 69,6 & 7,84 & 25,85 & 10,53 & 18,19 \\
Desv. Padrão & 4,64 & 1,26 & 3,33 & 2,68 & 11,4 & 2,95 & 4,22 & 3,62 & 3,27 \\
Valor máx. & 27,60 & 6,90 & 18,81 & 10,30 & 100,0 & 17,50 & 33,00 & 17,70 & 22,75 \\
Valor mín. & 0,00 & 1,50 & 2,00 & 0,00 & 43,0 & 2,40 & 16,80 & 1,20 & 9,95 \\
Total & 90,60 & 213,25 & - & - & - & - & - & - & - \\
Dias de chuva & 11 & - & - & - & - & - & - & - & - \\
\hline
\end{tabular}

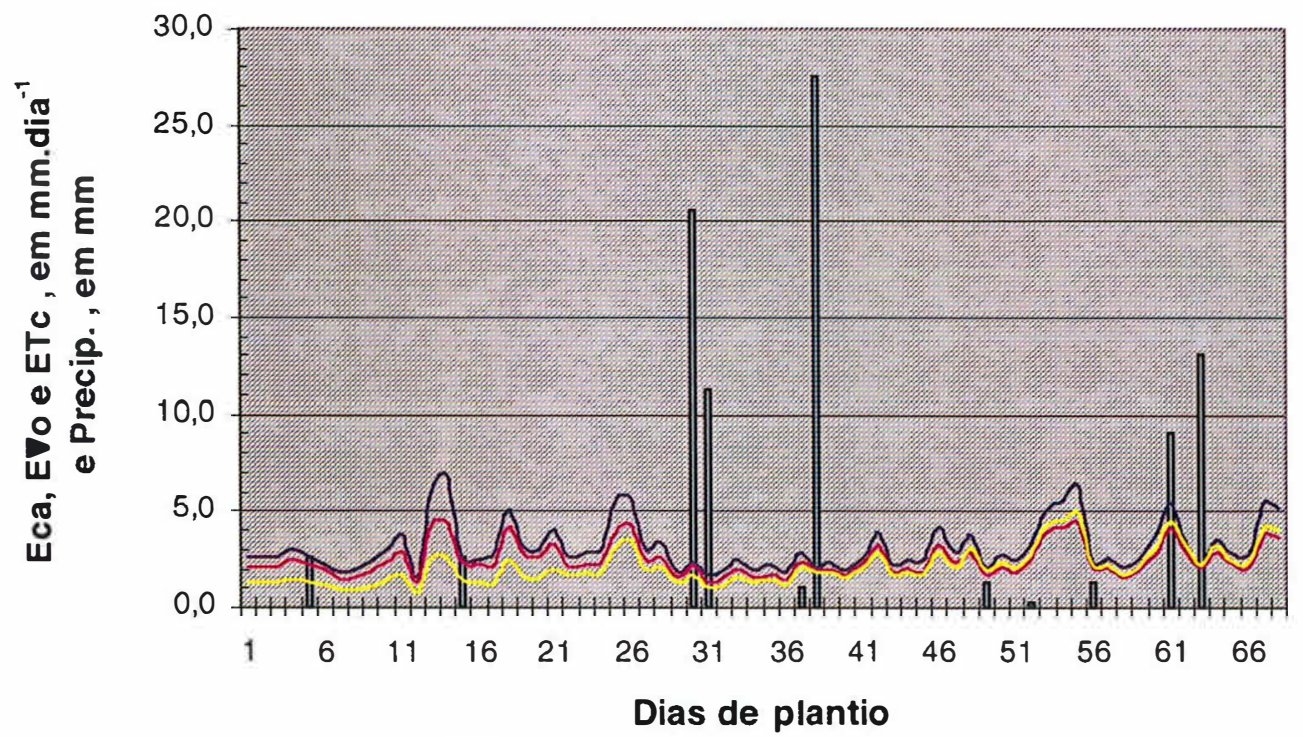

$\square$ Precip. - Eca - ETo ETc

Figura 14 - Seqüência dos valores registrados de evaporação do tanque Classe A (Eca), evapotranspiração de referência (ETo), evapotranspiração da cultura (ETc) e eventos de precipitação diária (Prec.), ocorridos durante o terceiro experimento. 
A análise de variância, para o conjunto de 240 dados da variável peso fresco (PF) e 208 dados da variável matéria seca (MS), realizada através do programa computacional SAS, usando-se o procedimento GLM, e tendo-se como modelo o efeito do fator dose do produto hidroretentor e o efeito do fator intervalo de irrigação, revelou ser significativa a interação entre os fatores estudados, ao nível de $1 \%$ de probabilidade, para as variáveis dependentes analisadas.

As médias das variáveis peso fresco (PF) e matéria seca (MS), para os tratamentos respectivos, são mostradas na Tabela 14.

Tabela 14. Valores médios obtidos para as variáveis peso fresco (PF) e matéria seca (MS), em cada tratamento de dose do produto (DOSE), para os respectivos intervalos de irrigação (INTER), no terceiro experimento.

\begin{tabular}{lccc}
\hline DOSE & INTER & $\begin{array}{c}\text { PF } \\
(\mathrm{g})\end{array}$ & $\begin{array}{c}\text { MS } \\
(\mathrm{g})\end{array}$ \\
\hline T0 & IR1 & 668,0 & 15,8 \\
T0 & IR3 & 598,8 & 15,7 \\
T0 & IR5 & 530,5 & 13,5 \\
T100 & IR1 & 605,9 & 16,6 \\
T100 & IR3 & 558,2 & 15,1 \\
T100 & IR5 & 639,0 & 16,4 \\
T200 & IR1 & 614,0 & 14,8 \\
T200 & IR3 & 604,8 & 18,5 \\
T200 & IR5 & 480,2 & 14,4 \\
T300 & IR1 & 556,6 & 14,1 \\
T300 & IR3 & 627,6 & 17,6 \\
T300 & IR5 & 601,4 & 14,3 \\
\hline
\end{tabular}


Para a comparação de médias entre os tratamentos, utilizou-se o procedimento GLM do programa SAS, para médias de quadrados mínimos, ajustadas para comparações múltiplas de Tukey-Kramer, onde obteve-se o seguinte :

a) variável peso fresco

Os resultados para a variável peso fresco (PF), quando da interação entre os tratamentos de dose do produto hidroretentor com os tratamentos de intervalo de irrigação, são mostrados na Tabela 15.

Tabela 15. Resultado da análise de comparação de médias para a variável peso fresco (PF), no terceiro experimento.

\begin{tabular}{clll}
\hline \multirow{2}{*}{ Tratamento } & \multicolumn{3}{c}{ Intervalo de Irrigação } \\
\cline { 2 - 4 } & \multicolumn{1}{c}{ IR1 } & \multicolumn{1}{c}{ IR3 } & \multicolumn{1}{c}{ IR5 } \\
\hline T0 & 668,0 a A & 598,8 ab A & 530,5 b BC \\
T100 & 605,9 a AB & 558,2 a A & 639,0 a A \\
T200 & 614,0 a AB & 604,8 a A & 480,2 b C \\
T300 & 556,6 a B & 627,6 a A & 601,4 a AB \\
\hline
\end{tabular}

Médias de intervalo de irrigação (IR) para a variável peso fresco (PF), seguidas de mesma letra minúscula (linha), não diferem entre si pelo teste de TukeyKramer ao nível de 0,05 de significância e médias de doses do produto (T) para a variável peso fresco (PF), seguidas de mesma letra maiúscula (coluna), não diferem entre si pelo mesmo teste e significância.

Analisando-se o efeito do fator intervalo de irrigação (IR), dentro de cada dose do produto, verificou-se que:

- para o tratamento de dose T0, IR1 diferiu significativamente de IR5 e não diferiu de IR3. Também, não houve diferença significativa entre IR3 e IR5; 
- para o tratamento de dose T100, não houve diferença significativa entre os tratamentos de intervalo de irrigação;

- para o tratamento de dose T200, IR1 e IR3 diferiram significativamente de IR5;

- para o tratamento de dose T300, não houve diferença significativa entre os tratamentos de intervalo de irrigação.

Analisando-se o efeito do fator dose do produto $(T)$, dentro de cada intervalo de irrigação, verificou-se que:

- para o tratamento intervalo de irrigação IR1, o tratamento T0 diferiu significativamente de T300, embora não tenha diferido de T200 e T100. Também, os tratamentos T200, T100 e T300 não diferiram entre si;

- para o tratamento intervalo de irrigação IR3, não houve diferença significativa entre os tratamentos de dose do produto;

- para o tratamento intervalo de irrigação IR5, o tratamento T100 diferiu significativamente de T0 e T200, embora não tenha diferido de T300.

Em relação à variação do intervalo de irrigação dentro de cada tratamento da dose do produto, para o tratamento TO a seqüência da diminuição das médias ocorreu dentro do que se era esperado, ou seja, IR1 > IR3 > IR5, onde a média de IR1 diferiu significativamente de IR5. Para o tratamento T300, não houve diferença significativa entre os tratamentos, com IR3 tendo a maior média em relação aos outros tratamentos, e IR5 maior que IR1.

Em relação à variação da dose do produto dentro de cada tratamento de intervalo de irrigação, para o IR5 os tratamentos T100 e T300 
tiveram as maiores médias em relação aos outros dois tratamentos (T0 e T200), e não diferiram significativamente entre si.

b) variável matéria seca

Os resultados para a variável matéria seca (MS), quando da interação entre os tratamentos de dose do produto hidroretentor com os tratamentos de intervalo de irrigação, são mostrados na Tabela 16.

Tabela 16. Resultado da análise de comparação de médias para a variável matéria seca (MS), no terceiro experimento.

\begin{tabular}{cccc}
\hline \multirow{2}{*}{ Tratamento } & \multicolumn{3}{c}{ Intervalo de Irrigação } \\
\cline { 2 - 4 } & IR1 & IR3 & IR5 \\
\hline T0 & 15,8 a A & 15,7 a A & 13,5 a A \\
T100 & 16,6 a A & 15,1 a A & 16,4 a A \\
T200 & 14,8 a A & 18,5 a A & 14,4 a A \\
T300 & 14,1 a A & 17,6 a A & 14,3 a A \\
\hline
\end{tabular}

Médias de intervalo de irrigação (IR) para a variável matéria seca (MS), seguidas de mesma letra minúscula (linha), näo diferem entre si pelo teste de TukeyKramer ao nivel de 0,05 de significância e médias de doses do produto $(T)$ para a variável matéria seca (MS), seguidas de mesma letra maiúscula (coluna), não diferem entre si pelo mesmo teste e significância.

Analisando-se o efeito do fator intervalo de irrigação (IR), dentro de cada dose do produto, verificou-se que:

- para os tratamentos de doses do produto T0, T100, T200 e T300 não houve diferença significativa entre as médias dos tratamentos de intervalo de irrigação (IR). 
Analisando-se o efeito do fator dose do produto $(T)$, dentro de cada intervalo de irrigação, verificou-se que:

- para os tratamentos de intervalo de irrigação IR1, IR3 e IR5, não houve diferença significativa entre as médias dos tratamentos de dose do produto $(\mathrm{T})$.

Em relação à variação do intervalo de irrigação dentro de cada tratamento de dose do produto, como também, em relação à variação da dose do produto dentro de cada tratamento de intervalo de irrigação, não houve diferença significativa entre os efeitos dos fatores estudados. A resposta da variável matéria seca (MS), em termos de ganho de massa, não foi sensível aos níveis dos tratamentos adotados no experimento e em relação ao regime de chuvas ocorrido durante o ciclo vegetativo da cultura.

\subsection{Considerações gerais}

A maior parte das pesquisas realizadas tem-se mostrado favorável ao emprego de polímeros hidroretentores em solos agrícolas, apresentando como fator de convergência a melhor utilização da água. Este fato tem ocorrido principalmente em regiões de clima árido ou semi-árido em solos de textura arenosa, que são caracterizados por sua baixa capacidade de retenção de água e pouca estruturação.

Em ensaios de laboratório, realizados por Prevedello et al. (2000), este mesmo tipo de polímero hidroretentor foi testado em dois meios porosos distintos (um solo com textura argilosa e uma areia marinha) acondicionados em colunas de solo na forma de TFSA, com variações na concentração do 
produto de 0 até $32 \mathrm{~kg} \cdot \mathrm{m}^{-3}$. Verificou-se, de modo geral, que a partir das concentrações de $8 \mathrm{~kg} \cdot \mathrm{m}^{-3}$, as propriedades físico-hídricas dos dois meios porosos foram dominadas pelo efeito dos polímeros, e que a capacidade de retenção de água no solo argiloso, para a concentração de $32 \mathrm{~kg} \cdot \mathrm{m}^{-3}$, foi acrescida cerca de 2 vezes.

No presente trabalho, o produto foi incorporado em canteiros numa camada de solo de $16 \mathrm{~cm}$ para a cultura da alface, onde a maior dose do produto utilizada foi de $300 \mathrm{~g} \cdot \mathrm{m}^{-2}$, o que corresponde a uma concentração de $1,875 \mathrm{~kg} \cdot \mathrm{m}^{-3}$.

Em termos estatísticos, para as variáveis analisadas, a interação entre o fator dose do produto hidroretentor e o fator intervalo de irrigação, nos tratamentos adotados, não revelou constância dos resultados observados nos experimentos realizados em três épocas diferentes de plantio.

Por esta razão, sugere-se que este trabalho tenha continuidade, propondo-se alterações na metodologia empregada, como na incorporação de doses maiores do produto hidroretentor em solos de textura argilosa, no aumento do intervalo de irrigação, em investigações na área de física de solos com a aplicação do produto em condições de campo, e principalmente na análise econômica sobre a viabilidade de utilização deste produto hidroretentor quando associado à prática da irrigação. 


\section{CONCLUSÕES}

Com base nos resultados obtidos, na metodologia utilizada e nas condições em que foram realizados os ensaios de laboratório e experimentos de campo, chegou-se às seguintes conclusões:

a) A equação do tipo potencial mostrou-se adequada ao ajuste dos dados obtidos no ensaio para caracterização da relação vazão vs. pressão, para o tipo de agulha descartável utilizado no tubo irrigador, cujo expoente de emissão determinado define o regime de escoamento no orifício como parcialmente turbulento e instável, no intervalo de pressão de 0,5 a 5,0 m.c.a. ;

b) O desenvolvimento de um sistema para aplicação de água nos canteiros do experimento pode ser aperfeiçoado, e vir a ser utilizado por horticultores que usem a forma de canteiros para plantio, em áreas com pouca declividade, e mesmo na produção de mudas, resultando em uma opção em relação aos sistemas de irrigação tradicionalmente utilizados em horticultura;

c) No ajuste das curvas de retenção de água do solo, verificou-se que a aplicação de doses crescentes do produto hidroretentor em um solo argiloso, resultou em um aumento gradual da umidade para uma mesma tensão, a partir da de 10,0 kPa ; 
d) A análise de variância revelou existir interação entre o efeito do fator dose do produto hidroretentor e o efeito do fator intervalo de irrigação, ao nível de $1 \%$ de significância, para as variáveis dependentes analisadas: peso fresco (PF) e matéria seca (MS);

e) Para a variável dependente peso fresco (PF), o teste de comparação de médias entre os tratamentos no experimento de outono (segundo experimento), onde houve pouca contribuição das chuvas durante o ciclo da cultura, não mostrou diferença significativa entre os mesmos, quando da interação do efeito do fator intervalo de irrigação no tratamento de maior dose do produto (T300). Já na interação do efeito do fator dose do produto no tratamento de maior intervalo de irrigação (IR5), mostrou que o tratamento (T300) diferiu estatisticamente, ao nível de $5 \%$ de probabilidade, dos demais. 


\section{REFERÊNCIAS BIBLIOGRÁFICAS}

AL DARBY, A.M. The hydraulic properties of a sandy soil treated with gelforming soil conditioner. Soil Technology, v.9, p.15-28, 1996.

BASTOS, E.A. Determinação dos coeficientes de cultura da alface (Lactuca sativa L.). Botucatu, 1994. 101p. Dissertação (Mestrado) - Faculdade de Ciências Agronômicas, Universidade Estadual Paulista "Júlio de Mesquita Filho".

BLANCO, M.C.S.G.; GROPPO, G.A.; TESSARIOLI NETO, J. Alface (Lactuca sativa). In: COORDENARORIA DE ASSISTÊNCIA TÉCNICA INTEGRAL. Manual Técnico das Culturas. 2.ed. Campinas, 1997 . v.2, p.13-18. (Manual CATI, 8).

BRANCO, A.A.; COUTO, F.A.A. Observaçōes sobre o efeito do azôto, fósforo e potássio na adubação da alface. Revista Olericultura, v.2, p.88-96, 1962.

COUTO, F.A.A.; BRANCO, A.A. Efeitos de fontes de azôto na fertilização de alface. Revista Olericultura, v.3, p.5-11, 1963.

DEMATTÊ, J.B.I.; CASSIANO SOBRINHO, F.; MENDONÇA, J.R. et al. Influência de irrigação por gotejamento e aspersão sobre desenvolvimento e produção da cultura de alface (Lactuca sativa L.) cv. 'Brasil-48'. Científica, v.9, n.2, p.207-213, 1981.

DOOREMBOS, J.; KASSAN, A.H. Yield response to water. Rome: FAO, 1979. 193p. (FAO. Irrigation and Drainage Paper, 33). 
DOURADO NETO, D.; NIELSEN, D.R.; HOPMANS, J.W.; PARLANGE, M.B. Programa computacional SWRC para Windows (versão 2.00): estimativa de parâmetros empíricos para curva de retenção de água no solo (compact disc) In: CONGRESSO LATINO-AMERICANO DE CIÊNCIA DO SOLO, 13., Águas de Lindóia, 1996. Solo-suelo 96: trabalhos. Piracicaba: SBCS/SLCS, 1996.

EL HADY, O.A.; PIEH, S.H.; OSMAN, S. Modified polyacrylamide hydrogels as conditioners for sandy soils. III. Influence on growth, water and fertilizers use efficiency by plants. Egyptian Journal of Soil Science, v.30, n.3, p.423432, 1990.

FILGUEIRA, F.A.R. Manual de olericultura: cultura e comercialização de hortaliças. 2.ed. São Paulo: Agronômica Ceres, 1982. v.2, 357p.

FOLEGATTI, M.V. Desenvolvimento do feijoeiro (Phaseolus vulgaris L.) submetido a diferentes lâminas médias de água através da irrigação por sulco. Piracicaba, 1985. 99p. Dissertação (Mestrado) - Escola Superior de Agricultura "Luiz de Queiroz", Universidade de São Paulo.

HAMADA, W.; TESTEZLAF, R. Desenvolvimento e produtividade da alface submetida a diferentes lâminas de água através de irrigação por gotejamento. Pesquisa Agropecuária Brasileira, v. 30, p.1201-1209, 1995.

KELLER, J.; KARMELI, D. Trickle irrigation design. Transactions of the American Society of Agricultural Engineers, v.17, p.678-684, 1974. 
LISBÃO, R.S.; NAGAI, H.; TRANI, P.E. Alface (Lactuca sativa L.). In: JORGE, J.A.; LOURENÇÃO, A.L.; ARANHA, C. (Ed.). Instruções agrícolas para o Estado de São Paulo. 2.ed. Campinas: IAC, 1994. p.11-12. (IAC. Boletim Técnico, 200).

NISSEN, M.J. Uso de hidrogeles en la producción de frambuesas (Rubus idaeus) del sur de Chile. Agro-Sur, v.22, n.2, p.160-165, 1994.

PREVEDELLO, C.L.; BALENA, S.P. Efeitos de polímeros hidroretentores nas propriedades físico-hídricas de dois meios porosos. Revista Brasileira de Ciência do Solo, v.24, n.2, p.251-258, 2000.

RAIJ, B. van; SILVA, N.M. da; BATAGLIA, O.C. et al. Recomendações de adubação e calagem para o Estado de São Paulo. Campinas: Instituto Agronômico, 1992. 107p. (IAC. Boletim Técnico, 100).

REICHARDT, K. Capacidade de campo. Revista Brasileira de Ciência do Solo, v.12, p.211-216, 1988.

SAAD, J.C.C.; SCALOPPI, E.J. Análise dos principais métodos climatológicos para estimativa da evapotranspiração. In: CONGRESSO NACIONAL DE IRRIGAÇÃO E DRENAGEM, 8., Florianópolis, 1988. Anais. Florianópolis: ABID, 1988. v.2, p.999-1021.

SALEM, N.; GUIDI, G.V.; PINI, R.; KHATER, A. The use of a polyacrylamide hydrogel to improve the water-holding capacity of a sandy soil under different saline conditions. Agricoltura Mediterranea, v.121, n.2, p.160-165, 1991.

SIMÃO, S. Irrigação da alface. Anais da Escola Superior de Agricultura "Luiz de Queiroz", v.13, p.121-128, 1956. 
SIMÃO, S. Adubação nitrogenada da alface. Revista de Agricultura, v.34, p.71-76, 1959.

SMAGIN, A.V.; SADOVNIKOVA, N.B. Impact of strongly swelling hydrogels on water-holding capacity of light textured soils. Eurasian Soil Science, v.27, n.12, p.26-34, 1995.

SNYDER, R.L. Equation for evaporation pan conversion. Journal of Irrigation and Drainage Engineering, v.118, p.977-980, 1992.

STANHILL, G. A comparison of methods of calculating potential evapotranspiration from climatic data. Israel Journal of Agricultural Research, v.11, p.159-171, 1961.

TERRACOTTEM. Guia Técnico. Curitiba: Cooperativa Interdisciplinar de Serviços Técnicos, 1998. 47p.

VAN GENUCHTEN, M.Th. A closed-form equation for predicting the hydraulic conductivity of unsaturated soils. Soil Science Society of America Journal, v.44, p.892-898, 1980. 